\title{
Relational Analysis of Talents' Turnover and Management Factors in Bank's Credit Card Center: An Empirical Analysis Based on Six Banks in Guangzhou
}

\author{
Lian Duan, Ling Yan \\ School of Economics, Jinan University, Guangzhou, China \\ Email: duanlian129@sina.com
}

How to cite this paper: Duan, L., \& Yan, L. (2018). Relational Analysis of Talents' Turnover and Management Factors in Bank's Credit Card Center: An Empirical Analysis Based on Six Banks in Guangzhou. Journal of Financial Risk Management, 7, 290-330.

https://doi.org/10.4236/jfrm.2018.73019

Received: July 2, 2018

Accepted: September 26, 2018

Published: September 29, 2018

Copyright $\odot 2018$ by authors and Scientific Research Publishing Inc. This work is licensed under the Creative Commons Attribution International License (CC BY 4.0). http://creativecommons.org/licenses/by/4.0/

\section{Open Access}

\begin{abstract}
The development of bank's credit card business faces serious challenges, and the bank employees' turnover is becoming increasingly serious. In view of this, this thesis takes the employees of the credit card department of the six banking institutions in Guangzhou as the research object, and explores the key factors that influence the talent turnover of Chinese banking industry in the current environment. An official questionnaire is designed for research. Combining with the actual situation of corporate and domestic and foreign research results, in addition to the relational analysis on salary and benefits, career promotion and management communication which are traditional issues, this thesis has constructed a relational model of internal and external factors in the context of performance-based high-pressure brought by market saturation and the impact of the emerging business of mobile payment and virtual credit cards business. This thesis is more scientifically and comprehensively used for analysis and discussion. The talent turnover of bank's credit card business is mainly due to the ambiguity in the development prospects of credit card business, the impact of mobile payment and emerging business of virtual credit card on employees' psychological expectations, the high pressure of employees' performance due to saturation of the credit card market, and the development of new consumer finance companies. Also, external work opportunities and other intricate internal and external factors lead to this result.
\end{abstract}

\section{Keywords}

Talent Turnover, Empirical Research, Human Resource Management, Credit Card 


\section{Introduction}

\subsection{Research Background}

With the increasingly fierce market competition in China's financial industry, increasingly stringent regulatory policies, the acceleration of marketization of interest rate, the acceleration of the financial media process, and increasingly complicated customer demands, impact of Internet finance are increasing. Because Banks' financing functions start to decline, simple traditional asset and liability businesses can no longer create considerable profits. According to The People's Bank of China "Statistics Report on Financial Institutions Loan Investment" over the years (The People's Bank of China, 2017), the scale of China's consumer credit balance has grown from 7.5 trillion Yuan in 2010 to 25.06 trillion Yuan in 2016.

At the same time, the loss of bank employees has become increasingly serious. Institutions are facing more and more difficulties and challenges in talent management.

\subsection{Research Purpose}

Now, the problem of talent turnover in bank's credit card centre and the stability of the talent team are particularly urgent. This thesis is based on previous studies of the talent turnover of other companies and a bank's credit card business. It takes the credit card employees of the six banking institutions in Guangzhou as the research object, exploring the relationship between talent turnover and management factors in the context of new competitive environment in the financial industry faced by banks. Based on the findings of empirical research, this thesis explores how banks can more effectively build a management system that stably and effectively trains and develops talent. By avoiding talent turnover, the core competitiveness of banking institutions can be improved and continuous development can be achieved.

\subsection{Research Content}

This topic intends to take the credit card business of the banking industry in Guangzhou as the research object, and conducts a systematic study on the talent turnover from the perspective of management. Through the status quo of the bank's credit card business in Guangzhou, the questionnaires on bank's credit card employees are used to analyze the causes of talent turnover. On this basis, the thesis optimizes the design of the human resources management system of the bank's credit card center and proposes countermeasures for the loss of credit card talent.

\subsection{Research Structure}

This thesis is composed of eight chapters:

Chapter 1 is introduction which introduces the research background and significance of this thesis, and briefly describes the objectives, contents and re- 
search methods of this research.

Chapter 2 refers to related concepts and literature review which introduces relevant concepts of talent definition and talent turnover, analyzes the theoretical research of talent turnover model, and reviews domestic and foreign researches on the factors affecting talent turnover.

Chapter 3 constructs the relational mode of talent loss and management factors.

Chapter 4 refers to research hypothesis and questionnaire design and introduces sample data and research methods.

Chapter 5 includes empirical research and problem analysis. Data analysis of the relationships between variables is performed through SPSSAU6.0, and the assumptions of different variables are verified. If the relationship is established, there is a relation between the variable and talent turnover; if the relationship is not established, there is no obvious relation between the variable and talent turnover.

Chapter 6 includes hypothesis verification and research findings which summarizes the relevant conclusions obtained through the analysis and the inspiration for the talent turnover in the field of bank's credit card business.

Chapter 7 refers to research conclusions and discussions on countermeasures on talent turnover.

Chapter 8 is conclusions and contains prospects which briefly describes some findings of studying, countermeasures of talent turnover in bank credit card center and looks into the distance.

\subsection{Research Significance and Features}

At present, there are many theoretical and empirical studies on talent turnover, but most of them focus on the research of a certain industry, and there are few detailed studies on a certain business sector of the banking industry, especially the study of bank's credit card talent turnover. This thesis has the following features compared to previous research theories and content.

\subsubsection{Research Significance}

This thesis is based on previous researches of the talent turnover of other companies and a bank's credit card business. It takes the credit card employees of the six banking institutions in Guangzhou as the research object. Theoretically, it explors the relationship between talent turnover and management factors in the context of new competitive environment in the financial industry faced by banks, which provide a new method of studying and improving the efficiency of human resource management. Practically speaking, this thesis explores how banks can more effectively build a management system that stably and effectively trains and develops talent. By avoiding talent turnover, the core competitiveness of banking institutions can be improved and continuous development can be achieved. 


\subsubsection{Features}

1) Uniqueness

The research in this thesis reflects the uniqueness of talent turnover in the credit card industry of the banking industry, further enriches the academic research on the talent turnover of employees, and also provides some help for the theoretical community in the related research of the banking industry.

2) Scientificity

This thesis selects six representative banks as the research objects, including state-owned banks, national joint-stock commercial banks, and local commercial banks, credit card center staff who received the questionnaires from all levels and positions of banks' credit card center. A total of 175 valid questionnaires were successfully obtained. The data are rich, authentic and complete.

\section{3) Accuracy}

This paper mainly analyzes the talent turnover of the bank's credit card business in Guangzhou, and uses SPSSAU6.0 software to perform statistical analysis methods such as cross-tab analysis, relational analysis, and chi-square test. The results of the research are more accurate and can stand the test. This has certain reference value for the academic community to continue the empirical analysis.

4) Significance

Bank's card commissions have been lowered continuously, and mobile payments and virtual credit cards have been developing rapidly. The bank's credit card business development is facing serious challenges, and the problem of the loss of bank's employees has become increasingly serious. An empirical analysis of the reasons for the loss of credit card talent has been made to upgrade banks which have great significance to development of credit card business.

\subsection{Research Method}

This thesis will use empirical research to examine the relation between talent turnover and human resource management in the bank's credit card business. This research identifies the intrinsic links between talent turnover and management factors in the industry and proposes solutions. The main research methods will include the following ways.

\subsubsection{Literature Analysis}

The author uses a large amount of literature on the Internet and libraries and browses domestic and foreign journals or professional academic research materials on professional talent management, conducting analysis and research on such issues as talent definitions, talent turnover models, and talent turnover factors.

\subsubsection{Interviews}

This study aims to address issues related to staff turnover and management factors, and plans to conduct open interviews with personnel of bank institutions' credit card business in the form of focus discussion, individual talks, telephone interviews, and on-line chats. It is to understand their needs and ideological 
trends for finding the most direct cause or motivation of talent turnover and seeking advice and ideas to improve the management capabilities of the company.

\subsubsection{Questionnaire Survey}

The relationship model is assumed to empirically analyze a group of 200 credit card employees in six banking institutions in Guangzhou. Through post-survey data analysis, the relevance of the hypothetical relational model was examined, and the relationship between talent turnover and management factors in the bank's credit card business is studied.

\subsubsection{Comparative Analysis}

According to the results of the questionnaire survey, groups of credit card employees of different banking institutions are compared and analyzed, such as gender, age, marital status, working years, employment forms, highest academic qualifications, and total income of the previous year.

\subsubsection{Empirical Analysis}

This thesis intends to empirically test the data obtained. Using SPSSAU6.0 tools, probability theory and statistical methods in mathematical statistics such as cross-tab analysis, relational analysis and chi-square test are employed. Also, this thesis establishes models and sets hypotheses with derivation and inductive method for giving scientific conclusion supported by data and facts.

This chapter mainly elaborates the research background, purpose, meaning, content and method, and confirms the subject of this research.

\section{Literature Review}

\subsection{Definition of Talent Turnover}

The talent turnover (Baidu Baike, 2016) refers to the phenomenon in which a person who plays an important role in the development of his or her business, even a key player, resigns initiatively or loses his active role. There is overt and covert loss of talents. The former refers to the company's talents leaving for some reasons and working for another company which causes difficulties for the company's human resources management, thereby affecting its operation and development. The latter refers to the company's talents who lose their motivation due to insufficient incentives or other reasons that their talents do not come into play, thereby affecting the company's development.

\section{Classification of Talent Turnover}

To correctly understand and measure talent turnover, talent turnover must be classified. There are two common categories of talent turnover for researchers: 1) According to the classification of decision maker, talent turnover can be divided into active loss and passive loss. The active loss refers to the decision made mainly by employees, including the active resignation of all employees. When the employee's wages or the marginal benefits they receive do not meet their ex- 
pectations, they may make decisions to leave the company, and become active loss. Passive loss also refers to organization's unwanted loss that decision are mainly made by organizations, including employee dismissal, layoffs, retirement and death; 2) In accordance with the impact of employee turnover on the organization, talent turnover can be divided into disadvantageous loss and advantageous loss.

\subsection{Model of Talent Turnover}

\subsubsection{March-Simon Model}

The March-Simon model (James et al., 1993), also known as the "actor-based decision-maker" model, is a relatively early and influential general model of employee turnover.

The model is actually composed of two models: one model studies the perceived rationality of turnover of the company, including two core factors, namely employee satisfaction and turnover possibility.

Another model analyzes the easiness of turnover of the company, the number of companies that employees can see the availability of qualified jobs, and the degree to which they are willing to accept these positions. These factors are determinants in this model.

This model has a logically clear picture of the factors influencing the behavior research of talent turnover, and has become an important theoretical basis for later talent turnover research.

\subsubsection{Price-Mueller Model}

American scholar Price (2001) has established an influential model to explain the psychological process of employee turnover: when employees are dissatisfied with the job, they will look for other opportunities within the organization. When they find a better chance, they will leave. When there are no suitable opportunities or opportunities are not good enough, they will stay in the organization with psychological tendency to leave.

From the perspective of the model as a whole, the Price-Mueller model is devoted to the analysis of the influential mechanism of intention to stay, and the variables that affect the intention to stay including five types of environmental variables, individual variables, structural variables, intermediary variables and control variables.

The environment variables include two variables: responsibility and opportunity of relatives. The responsibility of relatives refers to the obligation on relatives living in the same community; opportunity refers to the ease with which alternative jobs can be found. The model points out that these two variables can have direct and indirect effect on the loss, that is, they have an effect on job satisfaction.

The individual variables include three variables: general training, job involvement, and positive/negative emotions. General training refers to the extent to which employees' knowledge and skills can be used by other companies. Un- 
der normal circumstances, employers will increase their employees' salary, status, and rights to protect their own investments in special training for employees. This will reduce employees' job search behavior and loss intentions. Job involvement refers to the extent to which employees work hard and get rewarded. Increased returns are job satisfaction and organizational commitment.

The structured variables include seven variables: work autonomy, distribution fairness, job stress, salary, promotion opportunities, job monotony, and social support. Work autonomy refers to the extent to which employees control their own work rights. Distribution fairness refers to the extent to which the organization's rewards and penalties are linked to work performance. Work stress has four dimensions: lack of resources, role ambiguity, role conflict, and work overload. Salary refers to the money and other equivalents obtained as a result of working for the organization. Promotion opportunities are vertical occupational movements within the organization. Job monotony refers to the degree of work duplication. Social support includes the support level on work from the superiors, colleagues and relatives for work Support level.

Intermediary variables refer to job satisfaction, organizational commitment and job-seeking behavior. Job satisfaction refers to the extent to which employees like their work. Organizational commitment is the degree of employee loyalty to a social unit. Job-seeking behavior refers to the active level of employees looking for another job.

The Price-Mueller model abstracts and summarizes the external environment and the macro and micro factors of talent turnover. It clearly points out the types of variables and specific variables affecting the talent turnover and carefully points out the impact of environment, individual, structure, and process on the turnover behavior. It pointed out that the relationship between variables affecting turnover behavior and can be closely combine with the analysis of the causes of talent turnover.

\subsubsection{Mobley Mediation Model}

Mobley (1982) believes that research should focus on the behavioral and cognitive processes between employee satisfaction and the actual turnover rather than the simple correspondence between employee satisfaction and turnover. Mobley builds his own theoretical model of employee turnover selection on the basis of absorbing the advantages of the March-Simon model.

The model points out that: 1) If employees are dissatisfied with the existing work, they will have the idea of leaving the company; 2) After the idea is generated, they will seek an external evaluation; 3) Then, they will evaluate and choose the corresponding plans; 4) The intention of resignation comes to mind; 5) The final decision is to leave. Therefore, the resignation decision made by employees is a result of repeated measurement and adjustment. The main theoretical assumption of this model is that the reason why employees leave is not merely the result of the current low level of job satisfaction, but the final decision made after a comprehensive evaluation of various factors. 


\subsection{Research on Influential Factors of Talent Turnover at Home and Abroad}

At present, the research on the influencing factors of talent turnover can be divided into two types in the academia: 1) From the source of talent turnover, mainly analyzing the root cause of talent turnover, and thus implementing targeted management; 2) From the results of talent turnover, comparing study of various coping strategies to compensate for the negative impact and losses caused by talent turnover. The study of the talent turnover in the western countries was earlier. Scholars have conducted many researches from different levels and perspectives, formed many mature research results, and built theoretical models of talent turnover. Price (1977) believed that the main factors determining the talent turnover are: salary level, integration, tool-based communication (which directly affects the role of employees), formal communication (transmitting information through formal office channels), and centralization (centralization of power). Deery \& Shaw (1997) found that in addition to factors such as salary and job expectation, factors that affect talent turnover also include lack of effective communication between managers and employees, and lack of corporate culture. Hiltrop (1999) pointed out that the factors of talent turnover include: work remuneration, job challenges, training and promotion opportunities, socio-economic conditions, work schedules, job responsibilities, work autonomy, job security and career development opportunities. The study of talent turnover by domestic scholars began in the early 1990s, drawing on mature theoretical models to creatively study the talent turnover of companies based on the characteristics of different industries. Zhang \& Zhang (2003) sampled 470 technical employees of IT companies and used OLS regression analysis to conduct an empirical study of the Price's turnover intention model. Research shows that the model can better explain the intention of turnover of the samples in the researched industry. Combining with the actualization of China's industrialization process, Ye, Wang, \& Lin (2005) believed that the main factors affecting the loss of knowledgeable employees in high-tech companies in China are the employees' satisfaction with existing jobs and the degree to which employees' expectations are fulfilled. At the same time, the personal characteristics and non-work factors of employees also cause the turnover of employees. Also, employee's leaving behavior is also affected by external conditions such as supply and demand in the labor market and organizational constraints.

With regard to the causes of the talent turnover, the academic community and the business community have conducted joint discussions and achieved certain consensus and results. However, due to differences in research perspectives and methods, there is no consensus on this issue. From the current research on the factors of the talent loss of financial industry, the existing research is more about qualitative analysis and listing of various factors. There's lack of quantitative analysis of the various factors, as well as the study of the relationship between 
the various factors. The talent turnover of enterprises is a whole series of internal and external factors of a series of interconnected companies. With summary of previous research conclusions, the three main factors leading to the turnover decision are: the breakdown of psychological contract, work characteristics and the external environment.

This thesis analyzes the relevant literature of talent turnover of companies and concludes that the talent turnover factors are as follows: 1) Demographic factors: age, gender, job tenure, marriage, education background, family burden, etc.; 2) Work factors: remuneration, satisfaction with work comfort, integration, positive/negative emotions, professional reputation, career development opportunities, job challenges, job requirements, work autonomy, job engagement, job stress, job challenges, job complexity degree, job responsibilities, job promotion opportunities, tool-based communication, formal communication, corporate centralization, expectations for changing job roles within the company, management personnel and employee communication skills, management systems, training, fair distribution, etc.; 3) External environmental factors: policies, socio-economic situation, external job opportunities, etc.

In one word, it can be foreseen that bank's credit card personnel pay more attention to personal development space and opportunities.

Among the work factors, five factors such as work pressure, career development prospects, compensation and benefit, promotion opportunities, and work responsibilities that are more concerned with by credit card personnel are selected. Other work factors are basically included in these five factors. Because work emotions and other factors are not convenient to be scored in quantitative analysis due to the unclear meaning, these two factors are excluded. At the same time, management factors are added, and the influencing factors of enterprise management are attributed to the element of management communication. The external environmental factors have selected external job opportunities. The macroeconomic factors such as policies and economic conditions which are presented in external job opportunities have been excluded from external job opportunities. Finally, seven factors are obtained, as shown in Table 1.

Table 1. Influential factors of talent turnover.

\begin{tabular}{ccc}
\hline No. & Item & Factors \\
\hline 1 & S1 & Work pressure \\
2 & S2 & Career development prospects \\
3 & S3 & Compensation and benefit \\
4 & S4 & Promotion opportunities \\
5 & S5 & Management communication \\
6 & S6 & Job responsibilities \\
7 & S7 & external job opportunities
\end{tabular}




\title{
3. Construction of Rational Model of Talent Turnover and Management Factors
}

From previous research, it can be seen that the talent turnover may be influenced by one or more factors in the individual, organization and social factors at the same time. This thesis assumes that the tendency of the talent turnover of the bank's credit card business is directly related to the dynamic matching of management factors in banking institution, thereby constructing a related model of related factors of talent turnover in bank's credit card business. This thesis also assumes that management factors will affect employees' salary satisfaction, job satisfaction and career development satisfaction. According to these two hypotheses, the author constructs relational model of influential factors of talent turnover in bank's credit card business (Figure 1).

\section{Research Hypothesis and Questionnaire Design}

In order to better study the actual situation of the talent turnover of bank's credit card employees, the research is conducted on the basis of Weng (2009) “Questionnaire on Employees' Career Growth" and Chay \& Aryee (1999) and Garavan et al. (2006). The employees of bank's credit card center are interviewed individually. Combined with the organizational environment characteristics faced by the employees of bank's credit card center, 70 items that were combed are revised, and finally a formal questionnaire of 63 items was formed.

In order to eliminate the echo effect, this research employs the Likert-type 6-points scale, in which " 1 " means very unsatisfied, " 2 " means relatively unsatisfied, and " 3 " means somewhat unsatisfied. " 4 " means a little bit satisfied, “ 5 " means somewhat satisfied, and " 6 " means very satisfied. Participants are asked to choose the option that best fits their situation. Through a small sample test, the questionnaire has good internal consistency and reliability in the test, but also has a good structural validity.

\author{
Influential Factors of Brain Drain \\ Personal Information \\ Performance Pressure \\ Prospects of Career Development \\ Compensation and Benefits \\ Management Communication \\ Promotion Opportunities
}

\section{Other Influential Factors \\ External Job Opportunities}

Figure 1. Relational model of influential factors of talent turnover in bank's credit card business. 


\subsection{Questionnaire Design}

The total 6 categories of 63 questions are designed for this questionnaire (see Appendix). The first category focuses on the basic situation of employees; the second category examines the dimension of employees' loyalty imbalances; the third category examines the impact of employee turnover; the fourth category examines the assessment of response measures on talent turnover; the fifth category examines the subjectivity of internal and external reasons of employee turnover.

1) Basic information of employees: 7 items including gender, age, marital status, highest academic qualification, form of employment, working years, and total income of the previous year.

2) Assessment Scale of Employees' Loyalty Imbalance Dimension: this part of the questionnaire mainly refers to the three-factor model of Allen \& Meye (1990) and developed the "Questionnaire of Employees' Organizational Commitment for Chinese Enterprises” developed by Ling, Zhang, \& Fang (2000) and their research results. Employee loyalty has been divided into five dimensions: emotional loyalty, normative loyalty, ideal loyalty, economic loyalty, and opportunity loyalty. It has also been designed with reference to the scale of Ke Yuanzhen's (Ke, 2010)" Empirical Analysis on Corporate Loyalty of Enterprises' Core Employees with 15 questions.

3) Scale of Influential Factors of Employee Loss: this part contains 6 items such as job responsibilities, career development prospects, compensation and benefits, work responsibilities, promotion opportunities, and job responsibilities. Each item has 3 to 4 questions and is basically composed of the first-person declarative sentences.

The questions that respondents are asked to answer mainly present in three ways: The first is the objective choice question, which is mainly to investigate the basic situation of the respondent. The second type of questions, which is based on the Likert-type scale, covers aspects such as work pressure, career development prospects, compensation and benefits, promotion opportunities, management communication, and work responsibilities. The measurement for these elements is based on Likert-type 6-point scale. The third type is subjective problems which are mainly the investigation of the primary reasons for the resignation of employees, the prioritization of external job opportunities, and the specific measures for dealing with talent turnover.

\subsection{Method of Data Analysis}

SPSSAU6.0 is used to process and analyze the data. In addition to the reliability analysis of the questionnaire, cross-tab analysis, relational analysis, and chi-square test are used to analyze the relationship between variables.

\subsection{Research Hypothesis}

H1: There is a positive relationship between performance pressure of credit card business and employee turnover. 
H1a: There is a positive relationship between performance development pressure and employee turnover.

H1b: There is a positive relationship between the pressure on bad credit card rates and employee turnover.

H2: The development prospects of credit card business have a significant negative relationship with the employee's turnover of credit card business.

H2a: There is a positive relationship between the development expectations of mobile payment services and employee turnover.

H2b: There is a positive relationship between traditional credit card business and the employee's turnover in virtual credit card business.

$\mathrm{H} 2 \mathrm{c}$ : There is a positive relationship between the pressure of competition in the bank's credit card business and employee turnover.

H3: Low satisfaction rate of welfare center in credit card business is the first influential factor in talent turnover.

H3a: There is a negative relationship between compensation and employee turnover.

H3b: There is a negative relationship between fair distribution systems and benefits and employee turnover.

$\mathrm{H} 3 \mathrm{c}$ : There is negative relationship between labor income matching and employee turnover.

H4: Low maturity of management of credit card business has a significant positive relationship with talent turnover.

H4a: There is negative relationship between management communication and employee turnover.

H4b: There is a negative relationship between the smooth mechanism of information transmission of the company and the employee turnover.

H4c: There is negative relationship between promotion mechanism and employee turnover.

H4d: There is a negative relationship between reasonable and fair workload distribution and employee turnover.

H5: There is responsibility of employees of credit card center has a significant negative relationship with talent turnover.

H5a: There is a negative relationship between job challenges and employee turnover.

Based on the above discussion and assumptions, this research constructs the hypothesis model of loyalty influence factors as shown in Figure 2.

\subsection{Reliability Test}

In order to test the reliability and validity of the questionnaire, this research employees the "homogeneity reliability (using Cronbach's a coefficient)" method to test the influential factors of employee turnover and the dimension of loyalty imbalance on the reliability test. The test results are shown in Table 2 and Table 3. 


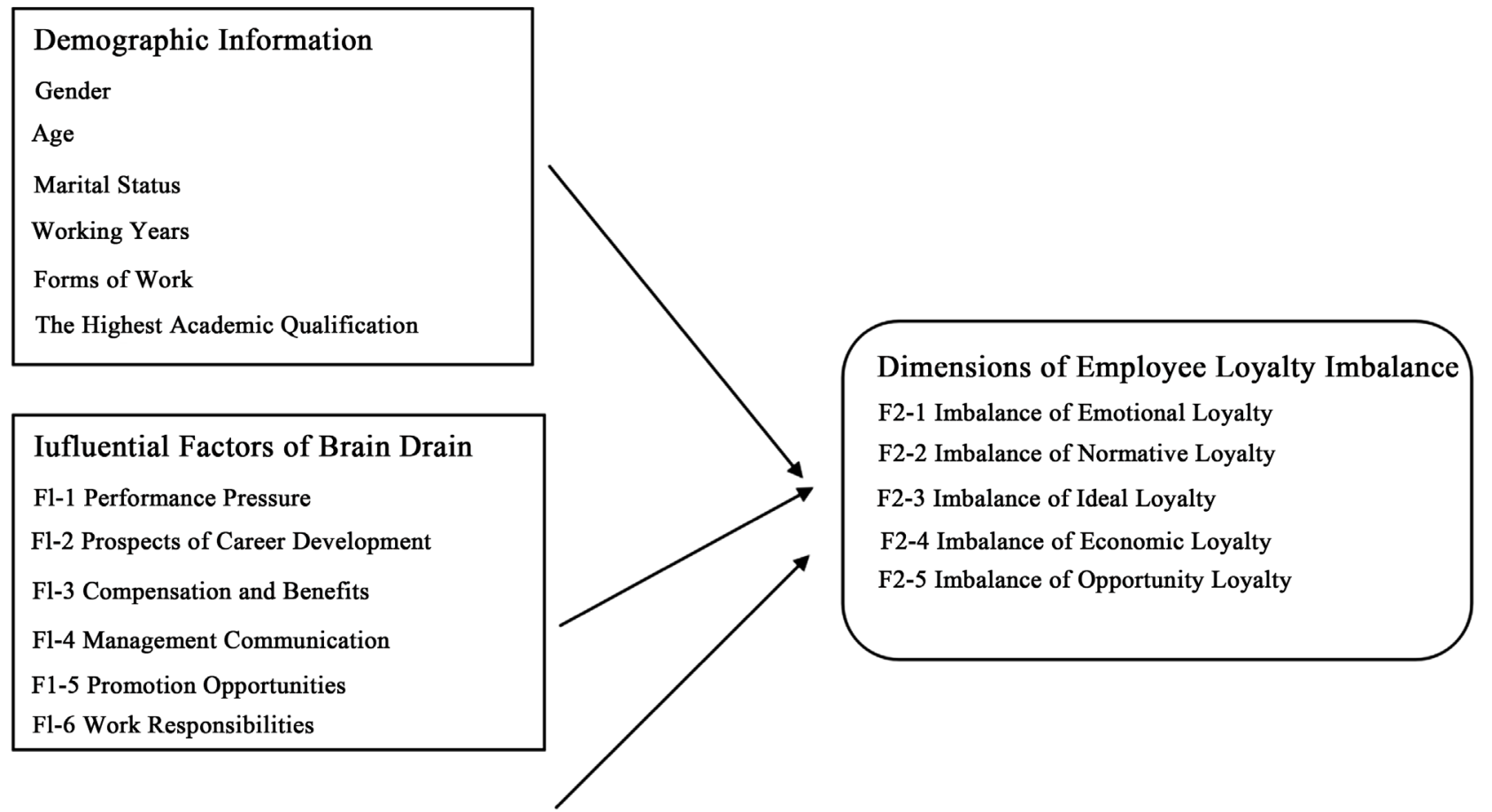

\section{Other Influential Factors}

External Job Opportunities

Figure 2. Hypothetical model for the employee turnover of credit card business.

Table 2. Reliability of influential factors of employee turnover $(\mathrm{N}=175)$.

\begin{tabular}{lc}
\multicolumn{1}{c}{ Influential Factors } & Homogeneity Reliability \\
\hline \multicolumn{1}{c}{ Total Reliability } & 0.834 \\
F1-1: Work Pressure & 0.880 \\
F1-2: Development Prospects of Industry & 0.848 \\
F1-3: Compensation and Benefits & 0.783 \\
F1-4: Promotion Opportunities & 0.903 \\
F1-5: Management Communication & 0.776 \\
F1-6: Job Responsibilities & 0.789 \\
\hline
\end{tabular}

Table 3. Reliability of employee loyalty imbalance $(\mathrm{N}=175)$.

\begin{tabular}{cc}
\hline Factors & Homogeneity Reliability ( $\boldsymbol{\alpha}$ coefficient) \\
\hline Total Reliability & 0.818 \\
F2-1: Imbalance of Emotional Loyalty & 0.818 \\
F2-2: Imbalance of Normative Loyalty & 0.770 \\
F2-3: Imbalance of Ideal Loyalty & 0.900 \\
F2-4: Imbalance of Economic Loyalty & 0.775 \\
F2-5: Imbalance of Opportunity Loyalty & 0.792 \\
\hline
\end{tabular}


In general, the reliability coefficient of 0.70 or more is in line with psychometric requirements. Table 2 and Table 3 show that the survey questionnaire of influential factors of employee turnover and loyalty as well as the overall homogeneity reliability of the factor all reach 0.80 or more, which ensures the reliability of the questionnaire. From the indicators of internal consistency, the homogeneity of the influencing factors is basically above 0.77 .

In terms of validity test, the questionnaire was modified based on the verified scales. After filling the questionnaires, the respondents were also asked for their opinions on the spot. The expression of questions in the questionnaire were repeatedly considered and modified. Then, market research was requested. Experts in the field checked the questionnaire and revised some of the items according to the results of the preliminary investigation. The above steps guaranteed the content validity of the questionnaire.

\section{Empirical Research and Question Analysis}

The data between variables are analyzed through SPSSAU6.0, and the assumptions of different variables are verified. If the relationship is established, there is a relationship between the variable and talent turnover. If the relationship is not established, there is no obvious relationship between the variable and talent turnover. Due to the need to confirm the questionnaire, data analysis is done after data collection.

\subsection{Descriptive Analysis of Sample Data}

The object of the questionnaire survey include existing employees of credit card center, managers of operation department, and some resigned employees of credit card center. 230 questionnaires were distributed, 201 were actually recovered, and questionnaires that did not answer the questions and answered logical contradictions were eliminated. Finally, 175 valid questionnaires were obtained and the effective recovery rate was $87 \%$.

The demographic information of the sample variables are shown:

1) In terms of gender, there are 53 males, accounting for $30.29 \%$; 122 females, accounting for $69.71 \%$. There is slightly more female banking staff. In terms of marital status, $56.57 \%$ are unmarried and $16 \%$ are married (no children), married (with children) accounted for $27.43 \%$, basically in line with the overall gender and marriage status of employees of credit card business.

2) In terms of age, the number of people aged between 26 - 30 is the highest, accounting for $44 \%$. In addition, employees under the age of 26 account for $33.14 \%$. The number of people aged $31-35$ account for $20.57 \%$. The number of people over the age of 36 account for $2.29 \%$. In general, the subjects are younger.

3) In academic background, subjects' academic qualifications are mainly concentrated in junior colleges and bachelor, with the largest number being bachelor and equivalents, accounting for $53.71 \%$, junior colleges and equivalents accounting for $43.43 \%$, master's degree or above accounting for $2.86 \%$. According 
to the distribution of academic qualifications of samples, the proportion of highly-educated persons (undergraduate and above) is slightly higher than that of the overall employees of credit card center. This is mainly due to the fact that this survey is mainly for formal employees of bank's credit card centers. When banks recruit regular employees from the society or campus, there will be clear academic requirements. The labor dispatching staffs of the credit card center have relatively low academic qualifications, but this survey did not issue a large number of survey questionnaires to Labor dispatching groups.

4) In terms of employment, the sample includes formal 137 middle and long-term contract workers, accounting for 78.29\%; 28 short-term contract workers, accounting for $16 \%$; and 3 laborers, accounting for $1.71 \%$. It's basically in line with the status quo of personnel structure of credit card.

5) In terms of the number of working years, there are $44.9 \%$ of the employees working for more than 10 years, $37.2 \%$ of the employees in $4-10$ years, $13.5 \%$ in 1 - 3 years, and $4.5 \%$ in one year. In general, the length of time for participants is mostly longer. This is mainly because the employees of state-owned enterprises are less mobile. Even if they are not willing to work in the current credit card center, the company can better arrange them to other suitable positions.

6) In the total revenue of the previous year, 50,000 - 100,000 accounted for $66.29 \%, 50,000-100,000$ accounted for $13.71 \%, 100,000-150$ thousand accounted for $12 \%, 150,000$ - 200 thousand accounted for 4\%, and 200,000 300,000 accounted for $2.86 \%$, more than 300,000 and $1.14 \%$. These are basically in line with the current status of the current income of employees of credit card center (Table 4).

\subsection{Cross-Tab Analysis and Chi-Square Test Based on Different Types of Comparison}

This part mainly analyzes the cross-tabulation of variables of individual characteristics such as gender, age, education, marital status, employment patterns, and working years of client managers, and discusses whether these variables are different in the dimensions of employee loyalty imbalance. The entire process is performed using the SPSSAU6.0 cross-tab analysis and chi-square test.

\subsubsection{Cross-Tab Analysis and Chi-Square Test of Gender Comparison}

In order to understand the difference in the gender dimension of the talent turnover of employees in credit card center, we conducted a cross-tab analysis and a chi-square test on employees of different gender in credit card centers. The analysis results are shown in Table 5.

The result show that the gender of employees of credit card center does not differ significantly in the three dimensions of emotional loyalty, normative loyalty and economic loyalty, but there are significant differences in the two dimensions of ideal loyalty and opportunity loyalty, that is, in the employee groups of credit card center, the effect of gender to loyalty on employees of credit card center is mainly focused on ideal loyalty and opportunity loyalty. It is generally 
Table 4. Variables situation of individual characteristics of samples $(\mathrm{N}=175)$.

\begin{tabular}{|c|c|c|c|}
\hline Items & Individual Characteristics & Numbers & Percentage \\
\hline \multirow[b]{2}{*}{ Gender } & Male & 53 & $30.29 \%$ \\
\hline & Female & 122 & $69.71 \%$ \\
\hline \multirow{5}{*}{ Age } & Under 26 years old & 58 & $33.14 \%$ \\
\hline & 26 - 30 years old & 77 & $44 \%$ \\
\hline & 31 - 35 years old & 36 & $20.57 \%$ \\
\hline & 36 - 50years old & 4 & $2.29 \%$ \\
\hline & 50 years old above & 0 & $0 \%$ \\
\hline \multirow{3}{*}{ Marital Status } & Unmarried & 99 & $56.57 \%$ \\
\hline & Married (No children) & 28 & $16 \%$ \\
\hline & Married & 48 & $27.43 \%$ \\
\hline \multirow{3}{*}{$\begin{array}{l}\text { The Highest } \\
\text { Academic } \\
\text { Qualification }\end{array}$} & Junior Colleges and Below & 76 & $43.43 \%$ \\
\hline & Bachelor & 94 & $53.71 \%$ \\
\hline & Master and Above & 5 & $2.86 \%$ \\
\hline \multirow{4}{*}{ Forms of Work } & Middle and Long-term Contract & 137 & $78.29 \%$ \\
\hline & Short-term Contract & 28 & $16 \%$ \\
\hline & Specific Contract & 7 & $4 \%$ \\
\hline & Labor dispatching & 3 & $1.71 \%$ \\
\hline \multirow[t]{3}{*}{ Items } & Individual Characteristics & Numbers & Percentage \\
\hline & Below 1 year & 30 & $17.14 \%$ \\
\hline & $1-3$ years & 87 & $49.71 \%$ \\
\hline \multirow{4}{*}{$\begin{array}{l}\text { Working Years In } \\
\text { Credit Card Center }\end{array}$} & $3-5$ years & 32 & $18.29 \%$ \\
\hline & $5-10$ years & 20 & $11.43 \%$ \\
\hline & $10-20$ years & 6 & $3.43 \%$ \\
\hline & Staffs & 155 & $88.57 \%$ \\
\hline \multirow[t]{4}{*}{ Position } & Line Managers & 16 & $9.14 \%$ \\
\hline & Middle-level Managers & 4 & $2.29 \%$ \\
\hline & Less than 50 thousand & 24 & $13.71 \%$ \\
\hline & $50-100$ thousand & 116 & $66.29 \%$ \\
\hline \multirow{4}{*}{$\begin{array}{l}\text { Total Income of the } \\
\text { Previous Year }\end{array}$} & $100-150$ thousand & 21 & $12 \%$ \\
\hline & $150-200$ thousand & 7 & $4 \%$ \\
\hline & $200-300$ thousand & 5 & $2.86 \%$ \\
\hline & More than 30 thousand & 2 & $1.14 \%$ \\
\hline
\end{tabular}

believed that male employees of credit card center are more concerned with the future and development prospects than female employees of credit card center. 
Table 5. Results of cross-tab analysis and chi-square test in each dimension of talent turnover on gender $(\mathrm{N}=175)$.

\begin{tabular}{ccc}
\hline Factors & $\mathrm{X}^{2}$ & $p$ \\
\hline Emotional Loyalty Imbalance & 11.849 & $0.037^{*}$ \\
& 16.077 & $0.007^{* *}$ \\
Normative Loyalty Imbalance & 3.688 & 0.595 \\
& 9.207 & 0.101 \\
Ideal Loyalty Imbalance & 21.064 & $0.001^{\star *}$ \\
& 12.048 & $0.034^{*}$ \\
Economic Loyalty Imbalance & 4.269 & 0.511 \\
& 12.759 & $0.026^{*}$ \\
& 7.789 & 0.168 \\
Opportunity Loyalty Imbalance & 18.765 & $0.002^{* *}$ \\
& 13.684 & $0.018^{*}$ \\
& 4.279 & 0.51 \\
& 2.724 & 0.742 \\
& 14.112 & $0.015^{*}$ \\
& 9.878 & 0.079 \\
\hline
\end{tabular}

\subsubsection{Cross-Tab Analysis and Chi-Square Test of Age Comparison}

This study divides the age of employees of credit card centers into five levels: 1 ) under 26 years old 2) 26 - 35 years old 3) 31 - 35 years old 4) 36 - 50 years old 5) over 50 years old. The analysis of variance and significance of each age group are shown in Table 6.

The results show that there are notable differences between the dimensions of imbalance of economic loyalty. There're no notable differences for the different age groups in the four dimensions of emotional loyalty imbalance, normative loyalty imbalance, ideal loyalty imbalance and opportunity loyalty imbalance. It means that age has not a significant relationship with the talent turnover of employees of credit card center. Previous studies have suggested that the older you are, the better you can be able to keep yourselves that you won't change your job easily. Grusky (1966) found that "organizational loyalty increases as the number of employees in the organization increases."

After further analysis, it can be seen that young employees of credit card center under the age of 30 choose "For opportunities and realization of ideals, I'm willing to break through the limitations of the existing family economic conditions". This is because young employees of credit card center under the age of 30 have age advantages and have been well-educated generally with advantages in foreign language proficiency, computer use, marketing skills, and even physical fitness. 
Table 6. Results of cross-tab analysis and chi-square test in each dimension of talent turnover on age $(\mathrm{N}=175)$.

\begin{tabular}{|c|c|c|}
\hline Factors & $\mathrm{X}^{2}$ & $p$ \\
\hline & 18.746 & 0.225 \\
\hline \multirow[t]{3}{*}{ Emotional Loyalty Imbalance } & 11.293 & 0.732 \\
\hline & 13.359 & 0.575 \\
\hline & 19.059 & 0.211 \\
\hline \multirow[t]{3}{*}{ Normative Loyalty Imbalance } & 18.203 & 0.252 \\
\hline & 23.292 & 0.078 \\
\hline & 13.302 & 0.579 \\
\hline \multirow[t]{3}{*}{ Ideal Loyalty Imbalance } & 19.133 & 0.208 \\
\hline & 11.175 & 0.74 \\
\hline & 14.346 & 0.499 \\
\hline \multirow{3}{*}{ Economic Loyalty Imbalance } & 15.232 & 0.435 \\
\hline & 26.629 & $0.032^{*}$ \\
\hline & 17.938 & 0.266 \\
\hline \multirow[t]{2}{*}{ Opportunity Loyalty Imbalance } & 12.389 & 0.649 \\
\hline & 12.713 & 0.624 \\
\hline
\end{tabular}

\subsubsection{Cross-Tab Analysis and Chi-Square Test of Marital Status Comparison}

In order to understand the differences in the dimensions of employee loyalty in credit card centers, variance analysis and significant tests on married and unmarried employees of credit card center are conducted. The analysis results are shown in Table 7.

The results show that there are no significant differences in the five dimensions of emotional credit loyalty, normative loyalty imbalance, ideal loyalty imbalance, economic loyalty imbalance and opportunity loyalty imbalance in employees of credit card center with different marital status. It follows that there is no significant relationship between marital status and talent turnover of employees of credit card center.

\subsubsection{Cross-Tab Analysis and Chi-Square Test of Forms of Employment Comparison}

There are two forms of employment for employees in credit card center, namely, contract staffs (regular staffs) and labor dispatching contract staffs (non-regular staffs). The analysis results are shown in Table 8.

The results show that there is no significant difference in the three dimensions of emotional loyalty $(p>0.05)$, economical loyalty imbalance $(p>0.05)$ and opportunity loyalty imbalance $(p>0.05)$ among employees of different types of employment forms; normative loyalty imbalance $(p=0.000<0.05)$ and ideal loyalty imbalance $(p=0.000<0.05)$, both of which have significant differences. 
Table 7. Results of cross-tab analysis and chi-square test in each dimension of talent turnover on marital status $(\mathrm{N}=175)$.

\begin{tabular}{ccc}
\hline Factors & $\mathrm{X}^{2}$ & $\boldsymbol{p}$ \\
\hline Emotional Loyalty Imbalance & 9.878 & 0.451 \\
& 9.167 & 0.516 \\
Normative Loyalty Imbalance & 10.89 & 0.366 \\
& 13.846 & 0.18 \\
Ideal Loyalty Imbalance & 10.317 & 0.413 \\
& 13.743 & 0.185 \\
& 11.978 & 0.287 \\
Economic Loyalty Imbalance & 12.137 & 0.276 \\
& 9.771 & 0.461 \\
& 15.2 & 0.125 \\
& 12.849 & 0.232 \\
Opportunity Loyalty Imbalance & 12.271 & 0.267 \\
& 6.161 & 0.802 \\
& 10.908 & 0.365 \\
& 11.479 & 0.321 \\
\hline
\end{tabular}

Table 8. Results of cross-tab analysis and chi-square test in each dimension of talent turnover on forms of elopement $(\mathrm{N}=175)$.

\begin{tabular}{ccc}
\hline Factors & $\mathrm{X}^{2}$ & $p$ \\
\hline Emotional Loyalty Imbalance & 9.999 & 0.441 \\
& 16.137 & 0.096 \\
Normative Loyalty Imbalance & 18.305 & 0.05 \\
& 19.307 & $0.037^{*}$ \\
& 36.678 & $0.000^{* *}$ \\
Ideal Loyalty Imbalance & 35.088 & $0.000^{* *}$ \\
& 10.923 & 0.364 \\
& 34.706 & $0.000^{* *}$ \\
Economic Loyalty Imbalance & 11.626 & 0.311 \\
& 13.635 & 0.19 \\
Opportunity Loyalty Imbalance & 7.579 & 0.67 \\
& 5.727 & 0.838 \\
& 8.907 & 0.541 \\
& 12.737 & 0.239 \\
& 13.918 & 0.177 \\
& & \\
& &
\end{tabular}


In general, formal staffs have deeper corporate loyalty and relevance to companies than regular staffs, and are higher than non-regular staffs in regulating loyalty and ideal loyalty. Non-regular staffs have no stable labor relations with strong liquidity, high turnover rates, and large salary fluctuations. They have little potential for development in this company, and their economic interests are more obvious ( $\mathrm{Wu}, 2010)$.

However, there are no significant differences between regular and non-regular staffs in the aspect of emotional loyalty imbalance, economic loyalty imbalance, and opportunity loyalty imbalance. This is closely related to the characteristics of sales positions. The first is that employees of credit card center in sales position earn sales commission on quality. Except for some social benefits such as housing provident funds that are slightly different between regular staffs and non-regular staffs, other incomes are generally equivalent. Sales earn money from their clients rather than their company. Having source of quality customers is the foundation for them. Second, in the credit card industry, state-owned banks, joint-stock banks, city commercial banks, rural commercial banks, and third-party payment companies are all making great efforts to develop credit card business. As long as employees of credit card center have certain working experience and marketing experience, they can attract interest of other bank which desire to hire excellent credit card sales. In the eyes of competitors, only customers and sales are valued, and forms of employees in credit card centers are not valued.

\subsubsection{Cross-Tab Analysis and Chi-Square Test of the Highest Academic Qualification Comparison}

This research divides the highest academic qualifications of employees of credit card center into: 1) high school and below 2) junior colleges and equivalent 3) bachelors and equivalent 4) masters and above. The analysis results are shown in Table 9.

The results show that there is no significant difference in the normative loyalty imbalance, economical loyalty imbalance and opportunity loyalty imbalance among employees of credit card centers with different educational backgrounds, but there are significant differences in the two dimensions of emotional loyalty and ideal loyalty, indicating that academic differences are not the important factor affecting employees of credit cards center on loyalty imbalance.

According to further analysis, employees of credit card center with bachelor's degree account for $53.71 \%$ of the total number, which is the backbone of the company. This group has advantages in terms of academic qualifications compared to junior college employees. The proportions of employees with master's or higher degree is small, but have received more attention from the management team because of high academic qualification. They have also demonstrated stronger qualities in their actual work so that the prospective opportunities for the promotion of the position are higher than those of employees with a bachelor's degree. Moreover, the distribution of salary is slightly higher. 
Table 9. Results of cross-tab analysis and chi-square test in each dimension of talent turnover on the highest academic qualification $(\mathrm{N}=175)$.

\begin{tabular}{|c|c|c|}
\hline Factors & $\mathrm{X}^{2}$ & $p$ \\
\hline & 23.022 & $0.011^{\star}$ \\
\hline \multirow[t]{3}{*}{ Emotional Loyalty Imbalance } & 14.61 & 0.147 \\
\hline & 7.381 & 0.689 \\
\hline & 9.776 & 0.46 \\
\hline \multirow[t]{3}{*}{ Normative Loyalty Imbalance } & 16.715 & 0.081 \\
\hline & 17.848 & 0.058 \\
\hline & 12.892 & 0.23 \\
\hline \multirow[t]{3}{*}{ Ideal Loyalty Imbalance } & 24.181 & $0.007^{* *}$ \\
\hline & 7.919 & 0.637 \\
\hline & 14.278 & 0.161 \\
\hline \multirow[t]{3}{*}{ Economic Loyalty Imbalance } & 7.798 & 0.649 \\
\hline & 7.286 & 0.698 \\
\hline & 10.805 & 0.373 \\
\hline \multirow[t]{2}{*}{ Opportunity Loyalty Imbalance } & 16.402 & 0.089 \\
\hline & 14.716 & 0.143 \\
\hline
\end{tabular}

\subsubsection{Cross-Tab Analysis and Chi-Square Test of Working Years Comparison}

This study divides the working years of employees of credit card center in the current company into four grades: 1) 1 years and below 2) 1 - 3 years 3) 4 - 10 years 4) 10 years and above. The analysis results are shown in Table 10.

The results show that there are no significant differences in the three dimensions of emotional loyalty imbalance, normative loyalty imbalance and opportunity loyalty imbalance in the current employees of credit card center of different working years, that is, the working years have little effect on the employee career development after the departure of credit card center. However, there are significant differences in the two dimensions of the ideal loyalty imbalance and economic loyalty imbalance. It means that the working year of current company has a significant effect on the loyalty of employees of credit card center.

It is generally believed that the longer the employees work in the company, the higher their loyalty to the company. Because they spend more time with company as they spend more time working in the company, they increasingly tie the company to their career planning, so they are not willing to leave. The new employees are just entering the company and are unfamiliar with new environment to which they are hard to adapt. They will choose to leave company if there is any change.

However, through further analysis, it can be seen that the length of work does not form a linear relationship with loyalty. The new employees who have just entered the job within a year are more loyal to the company. There are many 
Table 10. Results of cross-tab analysis and chi-square test in each dimension of talent turnover on working years $(\mathrm{N}=175)$.

\begin{tabular}{ccc}
\hline Factors & $\mathrm{X}^{2}$ & $\boldsymbol{p}$ \\
\hline Emotional Loyalty Imbalance & 22.905 & 0.294 \\
& 22.935 & 0.292 \\
Normative Loyalty Imbalance & 24.229 & 0.233 \\
& 16.212 & 0.703 \\
Ideal Loyalty Imbalance & 30.192 & 0.067 \\
& 31.257 & 0.052 \\
Economic Loyalty Imbalance & 40.939 & $0.004^{\star *}$ \\
& 35.752 & $0.016^{*}$ \\
& 23.943 & 0.245 \\
& 41.051 & $0.004^{* *}$ \\
& 25.09 & 0.198 \\
Opportunity Loyalty Imbalance & 18.637 & 0.545 \\
& 27.851 & 0.113 \\
& 30.012 & 0.07 \\
& 13.188 & 0.869 \\
\hline
\end{tabular}

reasons for this. Some of them feel confident in their future because of banks' high reputation and they can achieve rapid personal growth in the short term. They can get more job satisfaction, especially those who have just graduated from school. They are full of interest about the company and are willing to accept the challenges brought about by the work. Some of them didn't understand the company soon after coming to the company. Their relationships with other colleagues are simple and their appeal to the high position is not strong with low desire to high compensation.

\subsubsection{Cross-Tab Analysis and Chi-Square Test of Total Income of the Previous Year Comparison}

This study divides the total income in the previous year of employees of credit card center into 6 levels: 1) below 50 thousand; 2) 50 - 100 thousand; 3) 100 150 thousand; 4) 150 - 200 thousand; 5) 200 - 300 thousand; 6) 300 thousand and above. The analysis results are shown in Table 11.

The results show that there are no significant differences in the three dimensions of emotional loyalty imbalance, normative loyalty imbalance and economic loyalty imbalance between employees of different income in credit card center. However, there are significant differences in the two dimensions of ideal loyalty imbalance and opportunity loyalty imbalance.

Further studies have found that the higher the income of the credit card center, the longer the time for work in this field, the higher the academic qualification, the greater the number of external job opportunities, and the higher the 
Table 11. Results of cross-tab analysis and chi-square test in each dimension of talent turnover on total income of the previous year $(\mathrm{N}=175)$.

\begin{tabular}{ccc}
\hline Factors & $\mathrm{X}^{2}$ & $p$ \\
\hline Emotional Loyalty Imbalance & 22.629 & 0.599 \\
& 28.438 & 0.288 \\
Normative Loyalty Imbalance & 29.07 & 0.261 \\
& 14.785 & 0.946 \\
& 22.516 & 0.606 \\
Ideal Loyalty Imbalance & 35.934 & 0.073 \\
& 45.827 & $0.007^{* *}$ \\
Economic Loyalty Imbalance & 50.974 & $0.002^{\star *}$ \\
& 35.858 & 0.074 \\
& 28.918 & 0.267 \\
& 23.04 & 0.575 \\
& 24.382 & 0.497 \\
Opportunity Loyalty Imbalance & 21.345 & 0.673 \\
& 25.653 & 0.426 \\
& 42.897 & $0.014^{*}$ \\
\hline
\end{tabular}

demand for fulfillment of ideals. It's because the low economic pressure on these employees of credit card center. After the basic lives have been met, the future development will be more important. If company still cannot provide their personal development platform, they will choose to give up.

\section{Hypothesis Verification and Research Results}

This research employs a relationship test method to perform hypothesis testing by using SPSSAU6.0 statistical software. Overall, the hypothesis of this research mainly examines the relationship between influential factors of employee turnover and employee turnover in credit card centers. Since the independent variable of this research-the employee turnover influencing factor-employee loyalty imbalance has a multi-dimensional structure. Therefore, the test of the influencing factors not only needs to examine the mediating role of the variables as a whole, but more importantly, to find out which influential factors of employee turnover are used by the dimensions of variables to affect the employee loyalty imbalance variables.

\subsection{Relational Test between Influential Factors of Employee Turnover and Employee Turnover of Bank's Credit Card Center}

In the test of this relationship, the key is to examine whether the relationship between employee turnover and employee turnover (employee imbalance) is significant. 


\subsubsection{Relational Analysis}

In statistics, correlation analysis is used to study the uncertainty relationship between variables. It is a statistical method to study the closeness of linear relationship between variables. Based on the results of relational analysis, it can be initially determined whether each variable has an effect. The most commonly used statistic method for relational analysis is the Pearson correlation coefficient. $|R x y| \leq 1$, if $|R x y|$ is closer to 1 , then the linear relationship between variable $Y$ and variable $\mathrm{X}$ is more significant (Xue, 2013). In this research, the author analyzes the relationship between six variables in the influencing factors of employee loyalty scale and the five variables of employee loyalty to study the effect of each influencing factor on employee loyalty. The analysis results are shown in Table 12.

From the analysis results, under the significance level of 0.01 , each of the influencing factors has positive and negative relationship with different degrees in the five dimensions of employee loyalty imbalance, and the relationship coefficient is relatively high.

\subsubsection{Relational Test between Work Pressure of Bank's Credit Card Center and Employee Turnover}

As can be seen from Table 13, the comprehensive indicator of the factor of work pressure shows a significant positive relationship, supporting the theoretical hypothesis H1. The relationship between multi-dimension of business development pressure and reject ratio pressure and employee loyalty imbalance is $p<0.01$, showing a strong positive relationship, supporting the hypothesis H1a and H1b.

\subsubsection{Relational Test between Development Prospects of Credit Card Industry and Employee Turnover}

From Table 14, it can be seen that the comprehensive indicators of the factors of the industry's development prospects show a significant positive relationship, supporting the theoretical hypothesis $\mathrm{H} 2$. The development prospects of the mobile payment business and the impact of the virtual credit card on the traditional credit card business are related to the employee loyalty imbalance $p<$ 0.01 , showing a strong positive relationship, supporting the hypothesis that $\mathrm{H} 2 \mathrm{a}$ and $\mathrm{H} 2 \mathrm{~b}$ are established.

However, the pressure of horizontal competition, as can be seen from Table 13 , does not show a strong relationship with employee loyalty imbalance. Only in the dimension of opportunity loyalty imbalance, there is a positive relationship in horizontal competition pressure, assuming that $\mathrm{H} 2 \mathrm{c}$ does not hold.

In summary, there is a strong positive relationship between credit card performance pressures and industry development prospects for employee turnover. In the fierce competition environment of the bank's credit card business market, employees are faced with market development pressures, persistently rising reject rates, difficulty in collecting badly and new market entrants to third-party payment virtual credit cards. So, under the ambiguous background of the industry's development prospects, the greater the pressure of performance in bank's credit card business, the more likely it is that employees will be lost. 
Table 12. Relational analysis of influential factors of employee turnover and dimensions of loyalty imbalance $(\mathrm{N}=175)$.

\begin{tabular}{|c|c|c|c|c|c|c|}
\hline Influential Factors & Relationship & $\begin{array}{c}\text { Emotional } \\
\text { Loyalty } \\
\text { Imbalance }\end{array}$ & $\begin{array}{l}\text { Normative } \\
\text { Loyalty } \\
\text { Imbalance }\end{array}$ & $\begin{array}{c}\text { Ideal } \\
\text { Loyalty } \\
\text { Imbalance }\end{array}$ & $\begin{array}{l}\text { Economic } \\
\text { Loyalty } \\
\text { Imbalance }\end{array}$ & $\begin{array}{l}\text { Opportunity } \\
\text { Loyalty } \\
\text { Imbalance }\end{array}$ \\
\hline \multirow{12}{*}{$\begin{array}{c}\text { Work } \\
\text { Pressure }\end{array}$} & \multirow{12}{*}{$\begin{array}{c}\text { Pearson } \\
\text { Correlation } \\
\text { Significance }\end{array}$} & $0.218^{* *}$ & -0.072 & $0.259^{* *}$ & $0.270^{* *}$ & $0.379^{* *}$ \\
\hline & & $0.213^{\star *}$ & $0.193^{\star *}$ & $0.228^{\star *}$ & $0.210^{* *}$ & $0.329^{*}$ \\
\hline & & $0.174^{\star *}$ & 0.117 & $0.306^{* *}$ & 0.108 & 0.101 \\
\hline & & $0.204^{* *}$ & -0.022 & $0.323^{* *}$ & $0.265^{\star *}$ & $0.217^{* *}$ \\
\hline & & $0.211^{* *}$ & 0.084 & $0.227^{* *}$ & $0.176^{* *}$ & $0.201^{\star *}$ \\
\hline & & $0.162^{\star *}$ & $0.191^{* *}$ & $0.320^{\star *}$ & 0.039 & $0.222^{\star *}$ \\
\hline & & $0.150^{\star *}$ & -0.101 & $0.229^{\star *}$ & $0.224^{\star *}$ & $0.285^{\star *}$ \\
\hline & & 0.101 & 0.049 & 0.141 & $0.180^{* *}$ & $0.224^{* *}$ \\
\hline & & 0.111 & 0.1 & $0.250^{\star *}$ & 0.023 & $0.167^{* *}$ \\
\hline & & 0.049 & $-0.149^{\star *}$ & 0.119 & 0.112 & $0.266^{* *}$ \\
\hline & & -0.002 & -0.043 & 0.028 & 0.064 & $0.194^{\star *}$ \\
\hline & & -0.024 & 0.01 & $0.163^{* *}$ & 0.036 & 0.091 \\
\hline \multirow{13}{*}{$\begin{array}{c}\text { Industry } \\
\text { Development } \\
\text { Prospects }\end{array}$} & \multirow{13}{*}{$\begin{array}{c}\text { Pearson } \\
\text { Correlation } \\
\text { Significance }\end{array}$} & $0.249^{* *}$ & -0.093 & $0.492^{* *}$ & $0.435^{\star *}$ & $0.288^{\star *}$ \\
\hline & & $0.417^{* *}$ & $0.462^{* *}$ & $0.451^{* *}$ & $0.379^{* *}$ & $0.243^{* *}$ \\
\hline & & $0.273^{* *}$ & $0.386^{* *}$ & $0.469^{* *}$ & 0.016 & $0.233^{\star *}$ \\
\hline & & $0.167^{\star *}$ & -0.08 & $0.382^{* *}$ & $0.273^{* *}$ & $0.423^{* *}$ \\
\hline & & $0.240^{* *}$ & $0.191^{* *}$ & $0.297^{* *}$ & $0.198^{* *}$ & $0.368^{* *}$ \\
\hline & & 0.09 & $0.217^{* *}$ & $0.372^{* *}$ & $0.212^{* *}$ & $0.235^{* *}$ \\
\hline & & & & & & \\
\hline & & $0.163^{* *}$ & -0.066 & $0.311^{* *}$ & $0.189^{\star *}$ & $0.370^{* *}$ \\
\hline & & $0.204^{\star *}$ & 0.118 & $0.254^{\star *}$ & 0.136 & $0.230^{* *}$ \\
\hline & & 0.088 & 0.133 & $0.313^{* *}$ & $0.161^{* *}$ & 0.134 \\
\hline & & $0.200^{* *}$ & -0.057 & $0.359^{* *}$ & $0.241^{* *}$ & $0.313^{* *}$ \\
\hline & & $0.246^{* *}$ & $0.182^{* *}$ & $0.327^{* *}$ & 0.121 & $0.275^{* *}$ \\
\hline & & 0.096 & $0.219^{* *}$ & $0.370^{* *}$ & 0.074 & 0.113 \\
\hline \multirow{9}{*}{$\begin{array}{l}\text { Compensation } \\
\text { and Benefits }\end{array}$} & \multirow{9}{*}{$\begin{array}{c}\text { Pearson } \\
\text { Correlation } \\
\text { Significance }\end{array}$} & 0.129 & $0.192^{* *}$ & -0.003 & -0.087 & 0.084 \\
\hline & & -0.049 & -0.105 & $-0.209^{* *}$ & -0.097 & 0.025 \\
\hline & & -0.121 & -0.067 & -0.087 & 0.052 & 0.12 \\
\hline & & -0.033 & $0.288^{* *}$ & $-0.298^{* *}$ & $-0.283^{* *}$ & -0.009 \\
\hline & & $-0.222^{* *}$ & $-0.310^{\star *}$ & $-0.354^{* *}$ & $-0.248^{* *}$ & -0.107 \\
\hline & & $-0.252^{\star *}$ & $-0.342^{\star *}$ & $-0.274^{\star *}$ & 0.105 & -0.086 \\
\hline & & -0.103 & $0.216^{* *}$ & $-0.265^{\star *}$ & $-0.265^{\star *}$ & -0.031 \\
\hline & & $-0.305^{\star *}$ & $-0.268^{\star *}$ & $-0.380^{* *}$ & $-0.211^{* *}$ & -0.075 \\
\hline & & $-0.315^{\star *}$ & $-0.298^{* *}$ & $-0.325^{\star *}$ & 0.122 & -0.11 \\
\hline \multirow{6}{*}{$\begin{array}{c}\text { Promotion } \\
\text { Opportunities }\end{array}$} & \multirow{6}{*}{$\begin{array}{c}\text { Pearson } \\
\text { Correlation } \\
\text { Significance }\end{array}$} & -0.107 & $0.348^{* *}$ & $-0.370^{* *}$ & $-0.321^{* *}$ & $-0.179^{* *}$ \\
\hline & & -0.119 & $-0.415^{\star \star}$ & $-0.323^{\star *}$ & -0.142 & $-0.153^{\star *}$ \\
\hline & & $-0.225^{\star *}$ & -0.133 & $-0.374^{\star *}$ & 0.115 & -0.063 \\
\hline & & -0.056 & $0.402^{* *}$ & $-0.474^{* *}$ & $-0.428^{\star \star}$ & $-0.155^{\star *}$ \\
\hline & & $-0.222^{\star *}$ & $-0.439^{\star *}$ & $-0.423^{\star *}$ & $-0.267^{\star *}$ & $-0.189^{* *}$ \\
\hline & & $-0.271^{* *}$ & $-0.232^{\star *}$ & $-0.463^{\star *}$ & 0.129 & -0.112 \\
\hline
\end{tabular}




\section{Continued}

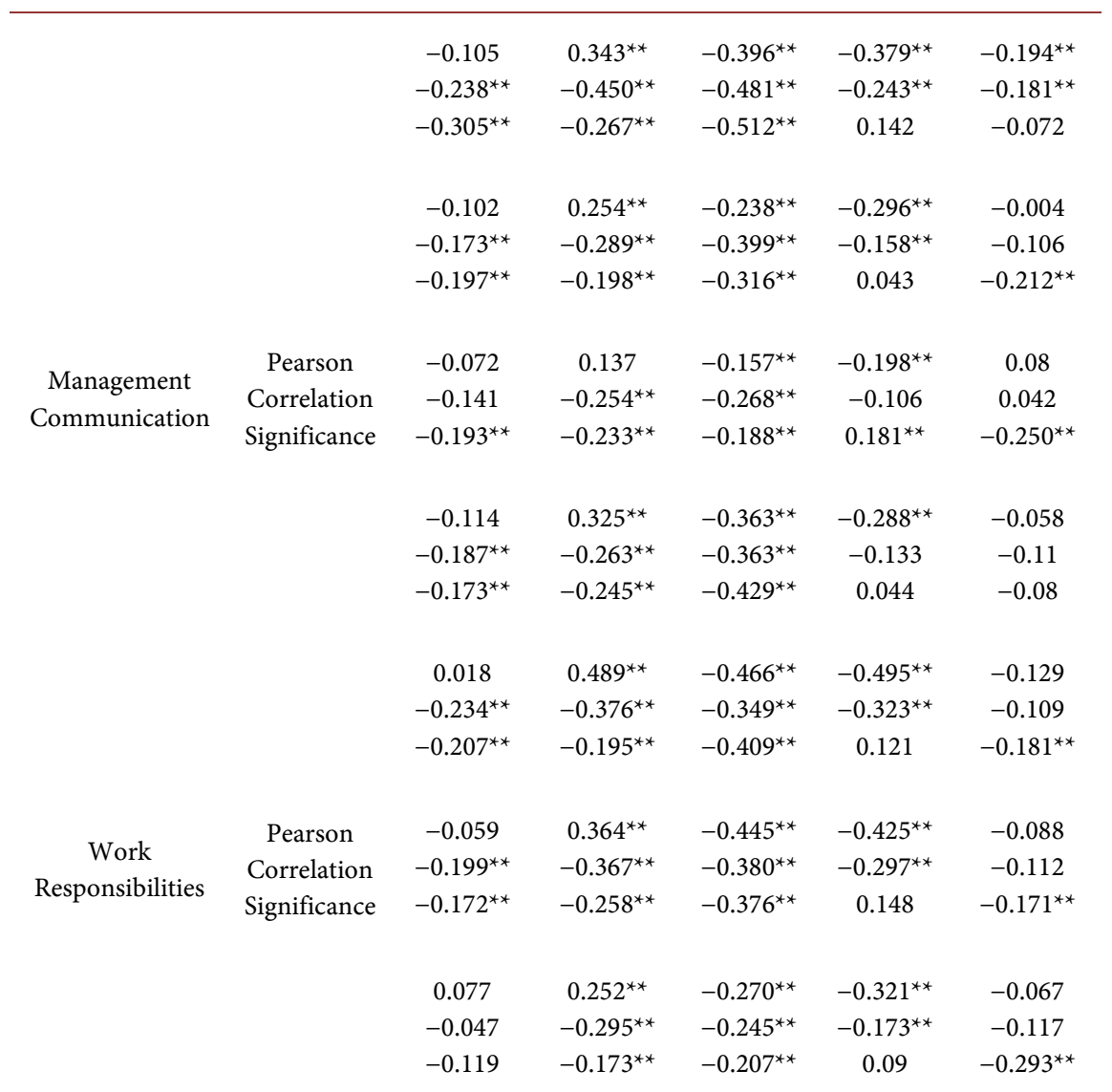

${ }^{\star} p<0.05 ;{ }^{* *} p<0.01$.

Table 13. Relational analysis of influential factors of work pressure and dimensions of loyalty imbalance $(\mathrm{N}=175)$.

\begin{tabular}{|c|c|c|c|c|c|c|}
\hline $\begin{array}{c}\text { Influential } \\
\text { Factors }\end{array}$ & Dimensions & $\begin{array}{c}\text { Emotional } \\
\text { Loyalty } \\
\text { Imbalance }\end{array}$ & $\begin{array}{l}\text { Normative } \\
\text { Loyalty } \\
\text { Imbalance }\end{array}$ & $\begin{array}{c}\text { Ideal } \\
\text { Loyalty } \\
\text { Imbalance }\end{array}$ & $\begin{array}{c}\text { Economic } \\
\text { Loyalty } \\
\text { Imbalance }\end{array}$ & $\begin{array}{l}\text { Opportunity } \\
\text { Loyalty } \\
\text { Imbalance }\end{array}$ \\
\hline \multirow{12}{*}{$\begin{array}{c}\text { Work } \\
\text { Pressure }\end{array}$} & Business & $0.218^{\star \star}$ & -0.072 & $0.259^{\star *}$ & $0.270^{\star *}$ & $0.379^{\star *}$ \\
\hline & Development & $0.213^{* *}$ & $0.193^{\star *}$ & $0.228^{\star *}$ & $0.210^{\star *}$ & $0.329^{* *}$ \\
\hline & pressure & $0.174^{\star \star}$ & 0.117 & $0.306^{\star *}$ & 0.108 & 0.101 \\
\hline & & $0.204^{\star *}$ & -0.022 & $0.323^{\star *}$ & $0.265^{\star *}$ & $0.217^{\star *}$ \\
\hline & & $0.211^{\star *}$ & 0.084 & $0.227^{\star *}$ & $0.176^{\star *}$ & $0.201^{\star *}$ \\
\hline & Ratio & $0.162^{\star *}$ & $0.191^{\star *}$ & $0.320^{\star *}$ & 0.039 & $0.222^{\star *}$ \\
\hline & pressure & $0.150^{* *}$ & -0.101 & $0.229^{\star *}$ & $0.224^{\star *}$ & $0.285^{\star *}$ \\
\hline & & 0.101 & 0.049 & 0.141 & $0.180^{\star *}$ & $0.224^{\star *}$ \\
\hline & & 0.111 & 0.1 & $0.250^{\star *}$ & 0.023 & $0.167^{\star \star}$ \\
\hline & Horizontal & 0.049 & $-0.149^{\star *}$ & 0.119 & 0.112 & $0.266^{* *}$ \\
\hline & Competition & -0.002 & -0.043 & 0.028 & 0.064 & $0.194^{\star \star}$ \\
\hline & Pressure & -0.024 & 0.01 & $0.163^{\star *}$ & 0.036 & 0.091 \\
\hline
\end{tabular}


Table 14. Relational analysis of influential factors of industry development prospects and dimensions of loyalty imbalance $(\mathrm{N}=175)$.

\begin{tabular}{|c|c|c|c|c|c|c|}
\hline $\begin{array}{c}\text { Influential } \\
\text { Factors }\end{array}$ & Dimensions & $\begin{array}{l}\text { Emotional } \\
\text { Loyalty } \\
\text { Imbalance }\end{array}$ & $\begin{array}{l}\text { Normative } \\
\text { Loyalty } \\
\text { Imbalance }\end{array}$ & $\begin{array}{c}\text { Ideal } \\
\text { Loyalty } \\
\text { Imbalance }\end{array}$ & $\begin{array}{l}\text { Economic } \\
\text { Loyalty } \\
\text { Imbalance }\end{array}$ & $\begin{array}{l}\text { Opportunity } \\
\text { Loyalty } \\
\text { Imbalance }\end{array}$ \\
\hline \multirow{4}{*}{$\begin{array}{c}\text { Industry } \\
\text { development } \\
\text { prospects }\end{array}$} & $\begin{array}{l}\text { No confidence } \\
\text { in the long-term } \\
\text { development on } \\
\text { banking industry }\end{array}$ & $\begin{array}{l}0.249^{* *} \\
0.417^{* *} \\
0.273^{* *}\end{array}$ & $\begin{array}{l}-0.093 \\
0.462^{\star *} \\
0.386^{* *}\end{array}$ & $\begin{array}{l}0.492^{* *} \\
0.451^{* *} \\
0.469^{* *}\end{array}$ & $\begin{array}{c}0.435^{\star *} \\
0.379^{\star *} \\
0.016\end{array}$ & $\begin{array}{l}0.288^{* *} \\
0.243^{* *} \\
0.233^{* *}\end{array}$ \\
\hline & $\begin{array}{l}\text { Market share } \\
\text { of credit card is } \\
\text { occupied by } \\
\text { mobile payment } \\
\text { business of third } \\
\text { party payment }\end{array}$ & $\begin{array}{c}0.167^{\star *} \\
0.240^{* *} \\
0.09\end{array}$ & $\begin{array}{c}-0.08 \\
0.191^{* *} \\
0.217^{* *}\end{array}$ & $\begin{array}{l}0.382^{\star *} \\
0.297^{\star *} \\
0.372^{* *}\end{array}$ & $\begin{array}{l}0.273^{* *} \\
0.198^{\star *} \\
0.212^{* *}\end{array}$ & $\begin{array}{l}0.423^{* *} \\
0.368^{* *} \\
0.235^{* *}\end{array}$ \\
\hline & $\begin{array}{l}\text { Impact brought } \\
\text { by mobile } \\
\text { payment }\end{array}$ & $\begin{array}{c}0.163^{* *} \\
0.204^{* *} \\
0.088\end{array}$ & $\begin{array}{c}-0.066 \\
0.118 \\
0.133\end{array}$ & $\begin{array}{l}0.311^{* *} \\
0.254^{* *} \\
0.313^{* *}\end{array}$ & $\begin{array}{c}0.189^{\star *} \\
0.136 \\
0.161^{\star *}\end{array}$ & $\begin{array}{c}0.370^{* *} \\
0.230^{* *} \\
0.134\end{array}$ \\
\hline & $\begin{array}{l}\text { Impact of } \\
\text { the virtual } \\
\text { credit card }\end{array}$ & $\begin{array}{c}0.200^{* *} \\
0.246^{* *} \\
0.096\end{array}$ & $\begin{array}{l}-0.057 \\
0.182^{* *} \\
0.219^{* *}\end{array}$ & $\begin{array}{l}0.359^{* *} \\
0.327^{* *} \\
0.370^{* *}\end{array}$ & $\begin{array}{c}0.241^{\star *} \\
0.121 \\
0.074\end{array}$ & $\begin{array}{c}0.313^{\star *} \\
0.275^{\star *} \\
0.113\end{array}$ \\
\hline
\end{tabular}

\subsubsection{Relational Test between Compensation and Benefits of Credit Card Centre and Employee Turnover}

As can be seen from Table 15, compensation and benefits are negatively correlated with employee turnover, but the relationship is weak and supports theoretical hypothesis H3. Unlike traditional perceptions, compensation and benefits are not the main cause of employee turnover. The fair distribution system and the matching of welfare and labor income with employee loyalty imbalances have a strong negative relationship, supporting the assumption that $\mathrm{H} 3 \mathrm{~b}$ and $\mathrm{H} 3 \mathrm{c}$. It means that the stable salary and benefits that meet the living expenses and fairness can better maintain the loyalty of employees. Therefore, the establishment of a reasonable, fair, and scientific remuneration system is an issue that company must pay attention to, and it is also an effective way to deal with the employees' turnover.

\subsubsection{Relational Test between Promotion Opportunities of Credit Card Centre and Employee Turnover}

As can be seen from Table 16, there is a strong negative relationship between promotion opportunities and employee turnover, supporting the theoretical hypothesis H4c. This shows that if employees feel that they have a future in their own company, they can be confident that they will work in their own company, thus retaining them and coping with the loss of employees.

\subsubsection{Relational Test between Management Communication of Credit Card Centre and Employee Turnover}

As can be seen from Table 17, there is a strong negative relationship between 
Table 15. Relational analysis of influential factors of compensation and benefits and dimensions of loyalty imbalance $(\mathrm{N}=175)$.

\begin{tabular}{|c|c|c|c|c|c|c|}
\hline $\begin{array}{c}\text { Influential } \\
\text { Factors }\end{array}$ & Dimensions & $\begin{array}{l}\text { Emotional } \\
\text { Loyalty } \\
\text { Imbalance }\end{array}$ & $\begin{array}{c}\text { Normative } \\
\text { Loyalty } \\
\text { Imbalance }\end{array}$ & $\begin{array}{c}\text { Ideal } \\
\text { Loyalty } \\
\text { Imbalance }\end{array}$ & $\begin{array}{l}\text { Economic } \\
\text { Loyalty } \\
\text { Imbalance }\end{array}$ & $\begin{array}{c}\text { Opportunity } \\
\text { Loyalty } \\
\text { Imbalance }\end{array}$ \\
\hline \multirow{9}{*}{$\begin{array}{l}\text { compensation } \\
\text { and benefits }\end{array}$} & \multirow{3}{*}{ Salary } & 0.129 & $0.192^{\star *}$ & -0.003 & -0.087 & 0.084 \\
\hline & & -0.049 & -0.105 & $-0.209^{\star *}$ & -0.097 & 0.025 \\
\hline & & -0.121 & -0.067 & -0.087 & 0.052 & 0.12 \\
\hline & Fair distribution & -0.033 & $0.288^{\star *}$ & $-0.298^{\star *}$ & $-0.283^{\star *}$ & -0.009 \\
\hline & system & $-0.222^{\star *}$ & $-0.310^{\star *}$ & $-0.354^{\star \star}$ & $-0.248^{\star \star}$ & -0.107 \\
\hline & and benefits & $-0.252^{\star *}$ & $-0.342^{\star *}$ & $-0.274^{\star \star}$ & 0.105 & -0.086 \\
\hline & Matching & -0.103 & $0.216^{\star *}$ & $-0.265^{\star \star}$ & $-0.265^{\star *}$ & -0.031 \\
\hline & of & $-0.305^{\star \star}$ & $-0.268^{\star *}$ & $-0.380^{\star \star}$ & $-0.211^{\star *}$ & -0.075 \\
\hline & labor income & $-0.315^{\star \star}$ & $-0.298^{\star *}$ & $-0.325^{\star *}$ & 0.122 & -0.11 \\
\hline
\end{tabular}

Table 16. Relational analysis of influential factors of promotion opportunities and dimensions of loyalty imbalance $(\mathrm{N}=175)$.

\begin{tabular}{|c|c|c|c|c|c|c|}
\hline $\begin{array}{c}\text { Influential } \\
\text { Factors }\end{array}$ & Dimensions & $\begin{array}{l}\text { Emotional } \\
\text { Loyalty } \\
\text { Imbalance }\end{array}$ & $\begin{array}{l}\text { Normative } \\
\text { Loyalty } \\
\text { Imbalance }\end{array}$ & $\begin{array}{c}\text { Ideal } \\
\text { Loyalty } \\
\text { Imbalance }\end{array}$ & $\begin{array}{l}\text { Economic } \\
\text { Loyalty } \\
\text { Imbalance }\end{array}$ & $\begin{array}{c}\text { Opportunity } \\
\text { Loyalty } \\
\text { Imbalance }\end{array}$ \\
\hline \multirow{10}{*}{$\begin{array}{c}\text { Promotion } \\
\text { opportunities }\end{array}$} & Frequent & -0.107 & $0.348^{\star *}$ & $-0.370^{* *}$ & $-0.321^{\star *}$ & $-0.179^{* *}$ \\
\hline & Training & -0.119 & $-0.415^{\star *}$ & $-0.323^{\star *}$ & -0.142 & $-0.153^{\star *}$ \\
\hline & opportunities & $-0.225^{\star *}$ & -0.133 & $-0.374^{\star *}$ & 0.115 & -0.063 \\
\hline & $\begin{array}{l}\text { Current job can } \\
\text { provide me with }\end{array}$ & -0.056 & $0.402^{\star *}$ & $-0.474^{\star *}$ & $-0.428^{\star *}$ & $-0.155^{\star *}$ \\
\hline & promotion and & $-0.222^{\star *}$ & $-0.439^{\star *}$ & $-0.423^{\star *}$ & $-0.267^{\star \star}$ & $-0.189^{\star \star}$ \\
\hline & $\begin{array}{l}\text { development } \\
\text { opportunities }\end{array}$ & $-0.271^{\star *}$ & $-0.232^{\star *}$ & $-0.463^{\star *}$ & 0.129 & -0.112 \\
\hline & The company & & & & & \\
\hline & has a very & -0.105 & $0.343^{\star *}$ & $-0.396^{* *}$ & $-0.379^{* *}$ & $-0.194^{\star *}$ \\
\hline & reasonable & $-0.238^{\star \star}$ & $-0.450^{\star *}$ & $-0.481^{\star \star}$ & $-0.243^{\star *}$ & $-0.181^{\star \star}$ \\
\hline & $\begin{array}{l}\text { promotion } \\
\text { mechanism }\end{array}$ & $-0.305^{\star *}$ & $-0.267^{\star \star}$ & $-0.512^{\star *}$ & 0.142 & -0.072 \\
\hline
\end{tabular}

Table 17. Relational analysis of influential factors of management communication and dimensions of loyalty imbalance $(\mathrm{N}=175)$.

\begin{tabular}{|c|c|c|c|c|c|c|}
\hline $\begin{array}{c}\text { Influential } \\
\text { Factors }\end{array}$ & Dimensions & $\begin{array}{l}\text { Emotional } \\
\text { Loyalty } \\
\text { Imbalance }\end{array}$ & $\begin{array}{c}\text { Normative } \\
\text { Loyalty } \\
\text { Imbalance }\end{array}$ & $\begin{array}{c}\text { Ideal } \\
\text { Loyalty } \\
\text { Imbalance }\end{array}$ & $\begin{array}{l}\text { Economic } \\
\text { Loyalty } \\
\text { Imbalance }\end{array}$ & $\begin{array}{l}\text { Opportunity } \\
\text { Loyalty } \\
\text { Imbalance }\end{array}$ \\
\hline \multirow{3}{*}{$\begin{array}{l}\text { Management } \\
\text { communication }\end{array}$} & $\begin{array}{c}\text { Superior } \\
\text { Communicate } \\
\text { with you } \\
\text { initiatively }\end{array}$ & $\begin{array}{l}-0.102 \\
-0.173^{\star \star} \\
-0.197^{\star \star}\end{array}$ & $\begin{array}{l}0.254^{\star *} \\
-0.289^{\star *} \\
-0.198^{\star *}\end{array}$ & $\begin{array}{l}-0.238^{\star \star} \\
-0.399^{\star \star} \\
-0.316^{\star \star}\end{array}$ & $\begin{array}{c}-0.296^{\star *} \\
-0.158^{\star *} \\
0.043\end{array}$ & $\begin{array}{c}-0.004 \\
-0.106 \\
-0.212^{\star *}\end{array}$ \\
\hline & $\begin{array}{l}\text { Smooth } \\
\text { communication } \\
\text { with colleagues }\end{array}$ & $\begin{array}{l}-0.072 \\
-0.141 \\
-0.193^{\star \star}\end{array}$ & $\begin{array}{c}0.137 \\
-0.254^{\star *} \\
-0.233^{\star *}\end{array}$ & $\begin{array}{l}-0.157^{\star \star} \\
-0.268^{\star \star} \\
-0.188^{\star \star}\end{array}$ & $\begin{array}{c}-0.198^{\star *} \\
-0.106 \\
0.181^{\star *}\end{array}$ & $\begin{array}{c}0.08 \\
0.042 \\
-0.250^{* *}\end{array}$ \\
\hline & $\begin{array}{l}\text { Smooth } \\
\text { information } \\
\text { channel } \\
\text { in company }\end{array}$ & $\begin{array}{l}-0.114 \\
-0.187^{\star *} \\
-0.173^{\star *}\end{array}$ & $\begin{array}{l}0.325^{\star \star} \\
-0.263^{\star \star} \\
-0.245^{\star \star}\end{array}$ & $\begin{array}{l}-0.363^{\star \star} \\
-0.363^{\star \star} \\
-0.429^{\star \star}\end{array}$ & $\begin{array}{c}-0.288^{\star *} \\
-0.133 \\
0.044\end{array}$ & $\begin{array}{l}-0.058 \\
-0.11 \\
-0.08\end{array}$ \\
\hline
\end{tabular}


management communication and employee turnover, supporting the theoretical hypothesis $\mathrm{H} 4 \mathrm{a}$.

At the same time, there is a strong negative relationship between having a smooth information channel and employee turnover, and supporting the theoretical hypothesis H4b. Bara Aram McGuiness (1998) believes that effective, open and candid communication is an important factor in employee loyalty. If there is a smooth information transmission mechanism in the company, employees can easily get some needed information. This can enhance employees' understanding of the company and bring employees closer to the company.

\subsubsection{Relational Test between Work Responsibilities of Credit Card Centre and Employee Turnover}

From Table 18, it can be seen that work responsibilities have a high negative relationship with employee turnover and support theoretical hypothesis $\mathrm{H} 5$. Among them, unlike traditional perceptions, job challenges are highly negatively related to employee turnover. It supports the theoretical hypothesis $\mathrm{H} 5 \mathrm{a}$, stating that employees want to be able to take on certain responsibilities at work and do challenging tasks which can increase their sense of job accomplishment and stimulate their initiative, creativity and sense of responsibility to maintain their enthusiasm for work.

\section{Discussion of Research Findings and Countermeasures of Talent Turnover}

Based on the analysis of related data conducted in the previous chapter and test results of the hypothesis, this chapter summarizes the research conclusions, explains the limitations and deficiencies of the study, and future research directions, and discusses the strategies for the employees' turnover of bank's credit card business.

Table 18. Relational analysis of influential factors of work responsibilities and dimensions of loyalty imbalance $(\mathrm{N}=175)$.

\begin{tabular}{|c|c|c|c|c|c|c|}
\hline $\begin{array}{c}\text { Influential } \\
\text { Factors }\end{array}$ & Dimensions & $\begin{array}{l}\text { Emotional } \\
\text { Loyalty } \\
\text { Imbalance }\end{array}$ & $\begin{array}{l}\text { Normative } \\
\text { Loyalty } \\
\text { Imbalance }\end{array}$ & $\begin{array}{c}\text { Ideal } \\
\text { Loyalty } \\
\text { Imbalance }\end{array}$ & $\begin{array}{l}\text { Economic } \\
\text { Loyalty } \\
\text { Imbalance }\end{array}$ & $\begin{array}{l}\text { Opportunity } \\
\text { Loyalty } \\
\text { Imbalance }\end{array}$ \\
\hline \multirow{3}{*}{$\begin{array}{c}\text { Work } \\
\text { responsibilities }\end{array}$} & $\begin{array}{c}\text { I like and } \\
\text { adapt to } \\
\text { my current job }\end{array}$ & $\begin{array}{c}0.018 \\
-0.234^{\star \star} \\
-0.207^{\star \star}\end{array}$ & $\begin{array}{l}0.489^{\star *} \\
-0.376^{\star *} \\
-0.195^{\star *}\end{array}$ & $\begin{array}{l}-0.466^{\star *} \\
-0.349^{\star *} \\
-0.409^{\star *}\end{array}$ & $\begin{array}{c}-0.495^{\star *} \\
-0.323^{\star *} \\
0.121\end{array}$ & $\begin{array}{l}-0.129 \\
-0.109 \\
-0.181^{\star \star}\end{array}$ \\
\hline & $\begin{array}{l}\text { The workload } \\
\text { is rationally } \\
\text { distributed }\end{array}$ & $\begin{array}{l}-0.059 \\
-0.199^{\star \star} \\
-0.172^{\star \star}\end{array}$ & $\begin{array}{l}0.364^{\star \star} \\
-0.367^{\star \star} \\
-0.258^{\star \star}\end{array}$ & $\begin{array}{l}-0.445^{\star *} \\
-0.380^{\star \star} \\
-0.376^{\star *}\end{array}$ & $\begin{array}{c}-0.425^{\star \star} \\
-0.297^{\star \star} \\
0.148\end{array}$ & $\begin{array}{c}-0.088 \\
-0.112 \\
-0.171^{\star \star}\end{array}$ \\
\hline & $\begin{array}{c}\text { Work is } \\
\text { challenging }\end{array}$ & $\begin{array}{c}0.077 \\
-0.047 \\
-0.119\end{array}$ & $\begin{array}{l}0.252^{\star *} \\
-0.295^{\star *} \\
-0.173^{\star *}\end{array}$ & $\begin{array}{l}-0.270^{\star *} \\
-0.245^{\star *} \\
-0.207^{\star *}\end{array}$ & $\begin{array}{c}-0.321^{\star *} \\
-0.173^{\star *} \\
0.09\end{array}$ & $\begin{array}{c}-0.067 \\
-0.117 \\
-0.293^{\star *}\end{array}$ \\
\hline
\end{tabular}




\subsection{The Main Causes of the Employees Turnover of Bank's Credit Card Business}

After analyzing the statistical data of this research questionnaire, the author finds out that the main reasons for the employees' turnover of credit card center are the following aspects: loyalty imbalance, unstable working environment, and small promotion space.

\subsubsection{Loyalty Imbalance}

Loyalty imbalance is the primary reason for the employees' turnover of credit card center. The employee loyalty imbalance dimension is related to gender, age, education, and marital status, form of employment, working years, and income. The imbalance of employee loyalty directly affects the employee turnover rate, employees' satisfaction with the company, and employees' work attitude. This has brought varying degrees of influence to the daily management of the company, the replacement cost of human resources, and the stability of the team of credit card center teams.

\subsubsection{Unstable Working Environment}

The unstable work environment is the second largest cause of employees' turnover of credit card center. Through questionnaires, this research focuses on data collection for currently employed staffs of credit card center. In the face of the current reasons for not leaving the company, the table shows that the stability of the work environment accounts for $57.14 \%$ of the reasons. Through comprehensive analysis, the working environment is divided into two dimensions. The first dimension is that banks, as representatives of China's financial industry, are favored by many outsiders for their stability. Second, if companies can provide a stable working environment, they will be an effective measure to cope with talent turnover.

In summary, based on the advantages of the bank's institutional management, through the improvement of the bank's internal talent flow mechanism or rotation mechanism, a stable working environment can be created, so that employees can foresee their career development path (Table 19).

Table 19. Questionnaire on causes that why employees of credit card center haven't leave $(\mathrm{N}=175)$.

\begin{tabular}{ccc}
\hline Items & Numbers & Percentage \\
\hline Job repayment is satisfactory. & 67 & $38.29 \%$ \\
The credit card center has a good prospect. & 54 & $30.86 \%$ \\
There's economic burden of family and life. & 79 & $45.14 \%$ \\
There's stable working environment. & 100 & $57.14 \%$ \\
I can't find better yet & 65 & $37.14 \%$ \\
Others & 6 & $3.43 \%$ \\
\hline
\end{tabular}




\subsubsection{Small Promotion Space}

Employees of the bank's credit card center believe that the small space for promotion is the main reason for choosing to leave. According to the questionnaire, the reasons for the most likely to leave are as shown in Table 20. The small promotion space leads to $54.86 \%$ of the employees choosing to leave. According to a comprehensive analysis, the credit card center employees will focus on their own development space. There are few opportunities, single forms, and weak pertinence in bank's promotion mechanism. This shows that the company must establish a bridge between company development and employee growth. It is necessary to better think about the relationship between the company's development goals and the employees' career development goals.

Employees often have strong motivation for success and a strong desire to pursue self-fulfillment. If an employee feels no hope for his future, he or she will doubt and be vulnerable to the seduction of outside companies. Therefore, companies must help their employees to plan their careers, so that each employee can see their own growth direction and growth space and feel the concern of the company. This helps employees to stay in the company and is more conducive to countermeasure to talent turnover.

However, the scientific individual career plan must be combined with the company's strategic plan. At the same time, the company must consciously help and guide the employees to formulate their career development plans, provide learning opportunities, and promote their sound development in favor of the organizational goals.

\subsubsection{Attribution to Convergence of Banking and Pan-Financial Industry} The proportion of employees leaving the bank's credit card center to the banking and the pan-financial industry has nearly converged. Through questionnaires, which channels will be given priority in external job opportunities, as shown in Table 21, 54.29\% of the financial institutions chose to switch to the pan-financial industry, and $53.71 \%$ of the inter-bank credit card centers. Generally, with the rapid development of the Internet finance, third-party payment

Table 20. Questionnaire on causes that why employees of credit card center leave $(\mathrm{N}=$ 175).

\begin{tabular}{ccc}
\hline Items & Numbers & Percentage \\
\hline Low income & 91 & $52 \%$ \\
Excessive pressure on performance & 82 & $46.86 \%$ \\
Limited future development & 31 & $17.71 \%$ \\
Small promotion space is small & 96 & $54.86 \%$ \\
Items & Numbers & Percentage \\
Low leadership management skills & 18 & $10.29 \%$ \\
Assessment is not transparent and scientific. & 22 & $12.57 \%$ \\
Work is not challenging. & 17 & $9.71 \%$ \\
Others & 13 & $7.43 \%$ \\
\hline
\end{tabular}


Table 21. Questionnaire of selection preference on external work opportunities of credit card center employees $(\mathrm{N}=175)$.

\begin{tabular}{ccc}
\hline Items & Numbers & Percentage \\
\hline Inter-bank credit card centers & 94 & $53.71 \%$ \\
Pan-financial industries & 95 & $54.29 \%$ \\
Other industries & 71 & $40.57 \%$ \\
\hline
\end{tabular}

companies and other pan-financial industry, the increasing popularity of mobile payment and virtual credit card product forms, bank credit card center staff will pay more and more attention to the development of the pan-financial industry. This shows that the bank's talent turnover has already faced the competition for talent from the pan-financial industry and financial institutions in the same industry.

\subsection{Compensation and Benefits Isn't the Primary Factor in Employee Turnover}

In this research, through relationship statistics, we can see that compensation and benefits are negatively correlated with employee turnover, but the relationship is weak. It means that compensation and benefits is the reason for the employees' turnover, but is not the main reason for the employees' turnover. Fair distribution system and benefits, labor income matching and employee loyalty imbalance show a strong negative relationship, stating that they can meet the living expenses, fair compensation and benefits, and better maintain employee loyalty. Therefore, the establishment of a reasonable, fair, and scientific remuneration system is an issue that companies must pay attention to, and it is also an effective way to deal with the employees' turnover. Conversely, in the countermeasures to talent turnover, compensation and benefits is not the most effective measures. Under the condition of limited room for promotion, enterprises should provide opportunities for employees to display their expertise as much as possible and use post matching to enable employees to do their best and follow the company's growth. Giving employees certain decision-making rights when appropriate and letting employees find a sense of belonging is an advantageous measure to cope with the employees' turnover.

\subsection{The Active Role of Employees Emphasizing on Challenging Work on Team Stability}

In the work of human resources management such as employee recruitment, employee development, and employee career promotion, the company should focus on the recruitment, training, and professional development of employees with active work characteristics, and expand the influence of this stability factor.

\section{Conclusion and Prospects}

This thesis takes the employees of the credit card center of the six banking insti- 
tutions in Guangzhou as the research object, and explores the key factors that influence the talent turnover of Chinese banking industry in the current environment. An official questionnaire is designed for research. Combining with the actual situation of domestic and foreign research results, in addition to the relational analysis on salary and benefits, career promotion and management communication which are traditional issues, this thesis has constructed a relational model of internal and external factors in the context of performance-based high-pressure brought by market saturation and the impact of the emerging business of mobile payment and virtual credit cards business. This thesis is more scientifically and comprehensively used for analysis and discussion.

\subsection{Findings}

Based on the theory of human resource management, this thesis takes the questionnaire of credit card center of six banks in Guangzhou as the research object. This paper analyzes and studies the key factors that affect the credit card talent turnover in Guangzhou under the current economic and social environment. The main conclusions are as follows:

First of all, the unstable working environment is the main reason for the talent turnover of credit card center.

Secondly, the establishment of reasonable, fair and scientific compensation system is an effective way for credit card center to deal with talent turnover. Compensation and benefits are still the reason for talent turnover, but not the main reason for talent turnover. Fair distribution system and welfare, matching income and labor, show a strong negative relationship with the imbalance of employee loyalty, indicating that stable, fair compensation and benefits, which can meet the living expenses, can maintain employee's loyalty.

Furthermore, the small space for promotion is the main reason for choosing to leave. The bank card credit card center employee will focus on the job opportunities from both the pan-finance industry and the financial institutions of the same industry. It shows that with the rapid development of the pan-finance industries such as Internet finance, third-party payment companies and other pan-finance industries, mobile payment and virtual credit card products are becoming increasingly popular. In addition to facing the impact of the Internet financial industry on the banking credit card business, it also directly faces the competition for talents from banks in its own pan-finance industry.

Finally, employees with active working characteristics are good at discovering opportunities, actively constructing relationships and participating in business activities, and actively changing the environment and promoting the stability of the team, which are the stable factors in the talent team. Different from the traditional perception, the high negative relationship between job challenge and employee turnover indicates that this kind of employee wants to take certain responsibilities and do challenging work, which will increase their sense of job achievement, stimulate their initiative, creativity and sense of responsibility to maintain their enthusiasm for work. 


\subsection{Countermeasures of Talent Turnover in Bank Card Center}

Based on the above conclusions, the corresponding measures to deal with the talent turnover of bank credit card center are as follows:

As for the reason for the talent turnover caused by the "unstable working environment", the measures can be taken into account. As representatives of China's financial industry, banks' stability is favored by many external talents. Bank can apply its advantages of the bank's institutional management. Through the improvement of the bank's internal talent flow mechanism or rotation mechanism, a stable working environment can be created, so that employees can foresee their career development path.

On changing the traditional view that "improving salary and welfare" is the most effective measure to cope with the talent turnover, we find that salary and welfare is still the reason of staff turnover, but it is not the main reason to affect the staff turnover. In the case of limited promotion space, the countermeasures of talent turnover can be considered, as far as possible to provide opportunities to employees to develop their talents, use post matching, so that employees can do their best. By giving employees certain decision-making power, employees find a sense of belonging, is a favorable measure to cope with talent turnover

With regard to the reasons for the talent turnover caused by "employees focusing on jobs from the pan-finance industry and peer financial institutions at the same time," banks may consider to develop their business in the area of Internet finance. The expansion of the new business areas will provide more room for promotion for employees, while taking advantage of the stability of the working environment of banks, combining compensation, welfare and staff career development, to cope with competition for talent from the pan-finance industry and the financial institutions of the same industry.

As for the conclusion that "the employee with active working characteristics is the stable factor of the talent team" through the empirical study, attention should be paid to the recruitment, training and career development of employees with active working characteristics, so as to expand the influence of this stable factor.

\subsection{Scientificity and Innovation}

This thesis selects six representative banks as the research objects, including state-owned banks, national joint-stock commercial banks, and local commercial banks, credit card center staff who received the questionnaires from all levels and positions of banks' credit card center. A total of 175 valid questionnaires were successfully obtained. The data are rich, authentic and complete.

The theoretical basis of this thesis is guided by the theoretical model of talent turnover studied by previous research. The research background is based on the high performance pressure brought by the current market saturation of the credit card business of banks, which is impacted by the business of Internet finance. The internal and external relationship model of the talent turnover and man- 
agement factors of bank credit card center can provide reference for further study and promote the human resource management of bank credit card business.

\subsection{Limitation and Prospects}

Although the solution proposed by this thesis closely combines the actual situation of the credit card centers of six banks in Guangzhou and obtains primary data, the dimension of the model is relatively single and limited. The parameter selection of dependent and independent variables is relatively small, the real data has deep digging space, and the in-depth analysis of the correlation between the data, need to be further refined and in-depth study.

The talent turnover of bank credit card center will be a dynamic development problem, which needs continuous attention and research. The factors that affect the talent turnover will be different in different periods. With the development of the talent team, the human resource strategy will follow up with the change of the external environment and the development of the bank. Banks' credit center should pay attention to the talent demand, which will lay the foundation for the sustainable development of the bank.

\section{Conflicts of Interest}

The authors declare no conflicts of interest regarding the publication of this paper.

\section{References}

Allen, N. J., \& Meye, J. P. (1990). The Measurement and Antecedents of Affective, Continuance and Normative Commitment to the Organization. Journal of Occupational Psychology. https://doi.org/10.1111/j.2044-8325.1990.tb00506.x

Baidu Baike (2016). Talent Turnover. https://baike.baidu.com/

Bara Aram McGuiness (1998). The Change in Employee Loyalty. Nursing Management.

Chay, Y., \& Aryee, S. (1999). Potential Moderating Influence of Career Growth Opportunities on Careerist Orientation and Work Attitudes: Evidence of the Protean Career Era in Singapore. Journal of Organizational Behavior.

Deery, M. A., \& Shaw, R. N. (1997). An Exploratory Analysis of Turnover Culture in the Hotel Industry in Australia. International Journal of Hospital Management, 16, 375-392. https://doi.org/10.1016/S0278-4319(97)00031-5

Garavan, T. N., O’Brien, F., \& O’Hanlon, D. (2006). Career Advancement of Hotel Managers since Graduation: A Comparative Study. Personnel Review, 35, 252-280. https://doi.org/10.1108/00483480610656685

Grusky, D. (1966). Career Mobility and Organizational Commitment. Administrative Science Quarterly, 10, 488-503. https://doi.org/10.2307/2391572

Hiltrop, J.-M. (1999). The Quest for the Best: Human Resource Practices to Attract and Retain Talent. European Management Journal, 17, 422-430. https://doi.org/10.1016/S0263-2373(99)00022-5

James, G., March, H., \& Simon, A. (1993). Organizations. Wiley-Blackwell.

Ke, Y. Z. (2010). An Empirical Study on Organizational Loyalty of Core Employees in 
Enterprises. Master Thesis, Chongqing: Chongqing University.

Ling, W. L., Zhang, Z. C., \& Fang, L. L. (2000). A Study on the Structural Model of Organizational Commitment in China. Journal of Management Science.

Mobley, W. H. (1982). Employee Turnover. Addison Wesley.

Price, J. (1977). The Study of Turnover. Amen: Laowa State University Press

Price, J. L. (2001). Reflections on the Determinants of Voluntary Turnover. Journal of International Manpower.

The People's Bank of China (2017). Financial Institutions Loans to Statistics Report.

Weng, Q. X. (2009). Study on the Mechanism of Career Growth on Employee Commitment and Turnover. Wuhan: Huazhong University of Science and Technology.

Wu, Z. (2010). A Study on the Motivation of Informal Employees in State-Owned Enterprises. Hefei: Anhui University.

Xue, W. (2013). SPSS Statistical Analysis Method and Its Application. Electronic Industry Press

Ye, R. S., Wang, Y. Q., \& Lin, Z. Z. (2005). An Empirical Study on the Effect of Job Satisfaction and Organizational Commitment on Employee Turnover in State-Owned Enterprises. Management World.

Zhang, M., \& Zhang, D. (2003). Study on Factors Affecting Employee Turnover in IT Enterprises. Chinese soft Science. 


\section{Appendix: Credit Card Center Talent Turnover Questionnaire}

Distinguished colleagues:

The main purpose of this investigation is to listen to the voice of front-line business personnel, to understand the needs of business personnel, to create organizational culture suitable for the development of business personnel, and to improve the management quality and management level of credit card centers in banks. Your opinions and opinions are crucial to the future of the company. In this questionnaire, we need to know what you really think. This questionnaire is not filled in by secret. All responses will be strictly confidential and will be included in the general information for analysis report. There is no right or wrong answer, please answer according to your actual situation, no one else undefined influence.

BEGIN

\section{Part One: BASIC INFORMATION:}

1) Gender:

A. Male

B. Female

2) Age:

A. Under 26 years old

B. 26 - 30 years old

C. 31 - 35 years old

D. 36 - 50 years old

E. 50 years old above

3) Working Years In Credit Card Center:
A. Below 1 year
B. 1 - 3 years
C. 3 - 5 years
D. 5 - 10 years
E. 10 - 20 years
4) The Highest Academic Qualification:
A. Junior Colleges and Below
B. Bachelor
C. Master and Above
5) Forms of Work:

A. Middle and Long-term Contract

B. Short-term Contract

C. Specific Contract

D. Labor dispatching

6) Position:
A. Staffs
B. Line Managers
C. Middle-level Managers
7) Marital Status: 


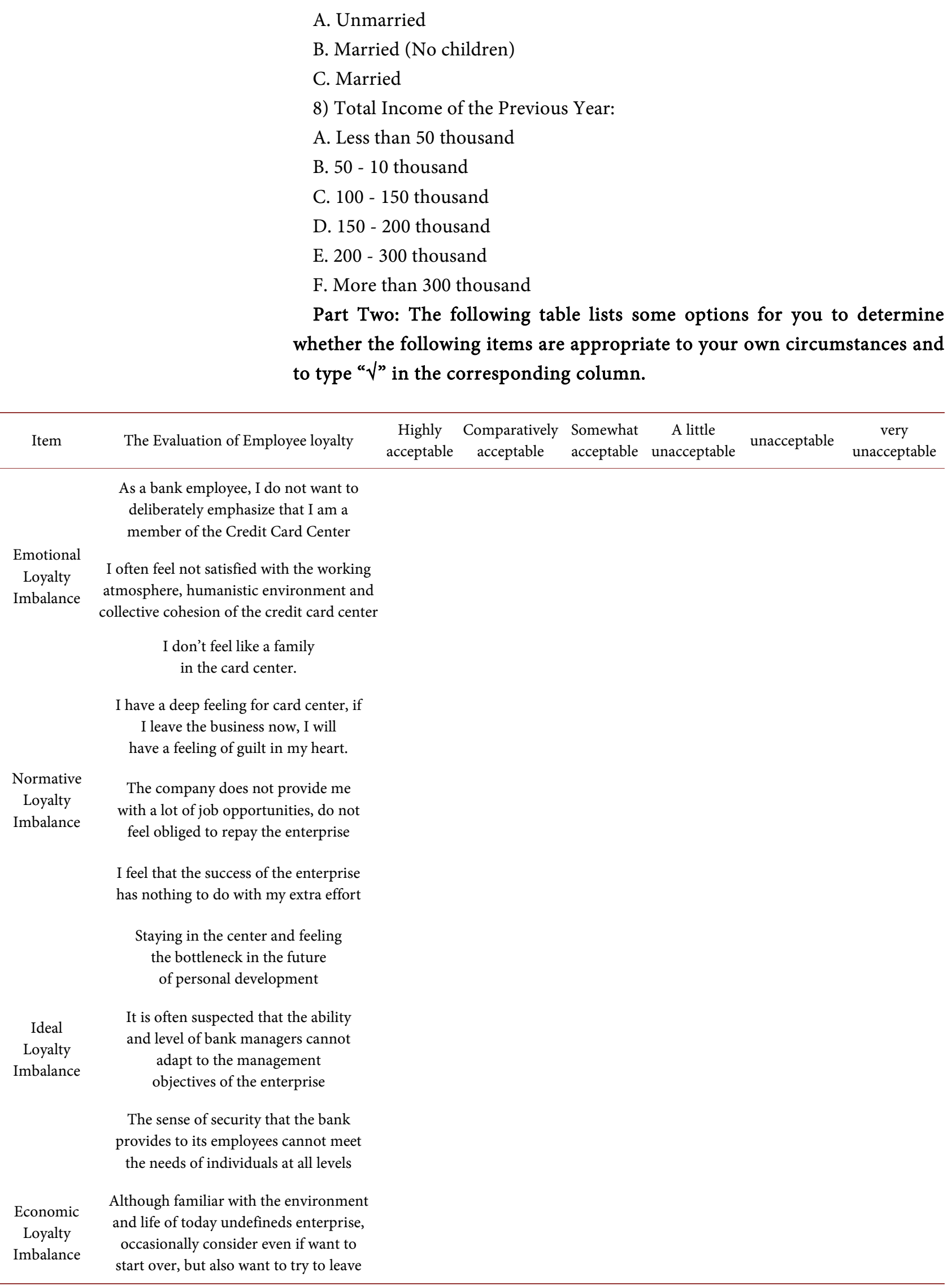




\section{Continued}

Not afraid to lose the decent
pay and benefits available
Willing to work and break through the
constraints of existing family economic
conditions for the sake of opportunity
and the realization of ideals
Regular and ongoing recruitment
of staff among banks
With objective reality, it is not
difficult to find a more suitable unit
$\begin{gathered}\text { Loyalty } \\ \text { Imbalance } \quad \text { In order to retain the staff, the company } \\ \text { made the appropriate comfort and } \\ \text { compromise, but I do not }\end{gathered}$
want to change the decision to leave.

Part Three: please make a judgment on the factors affecting the talent turnover in the following table and type " $\sqrt{ }$ " in the most objective corresponding column.

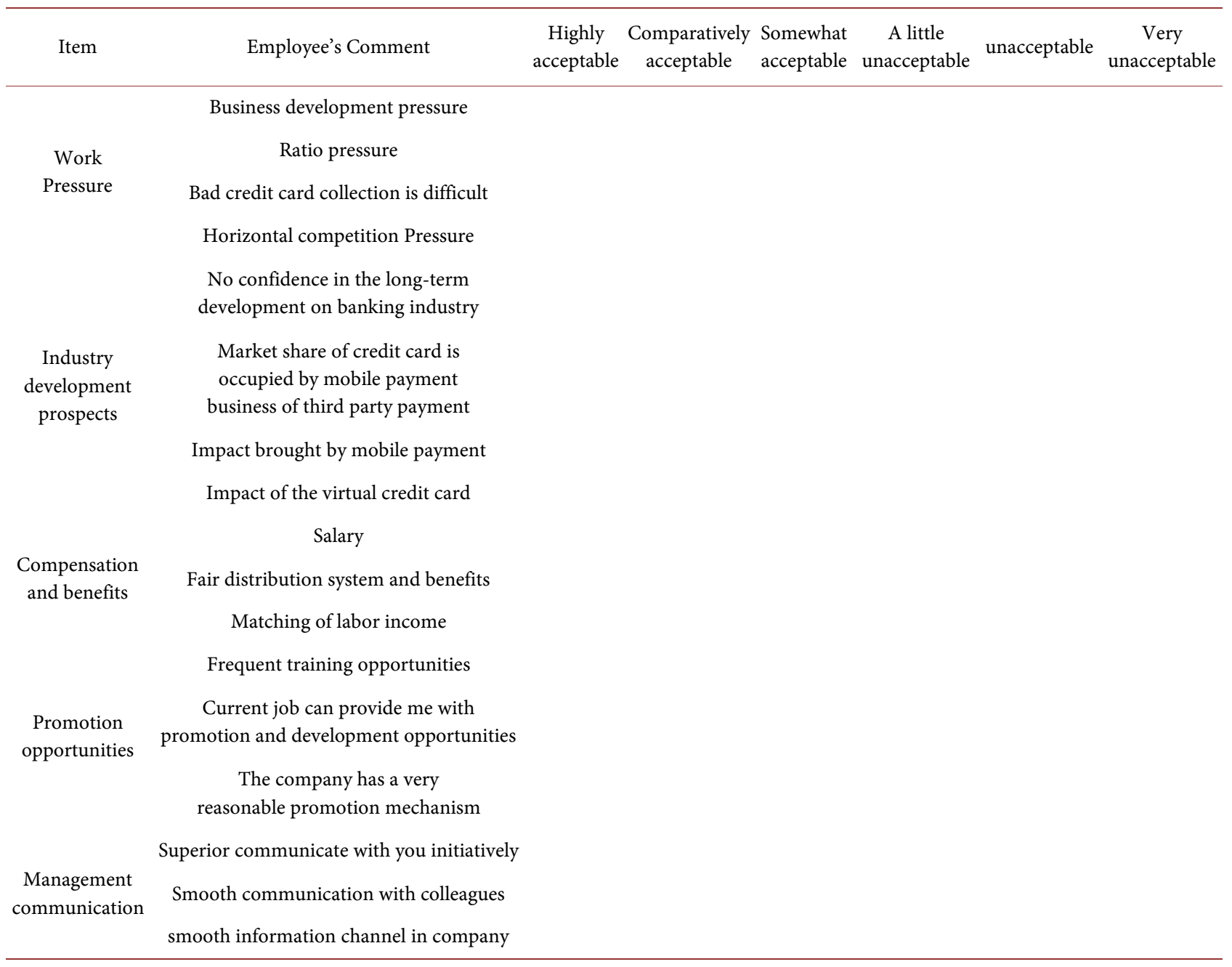




\section{Continued}

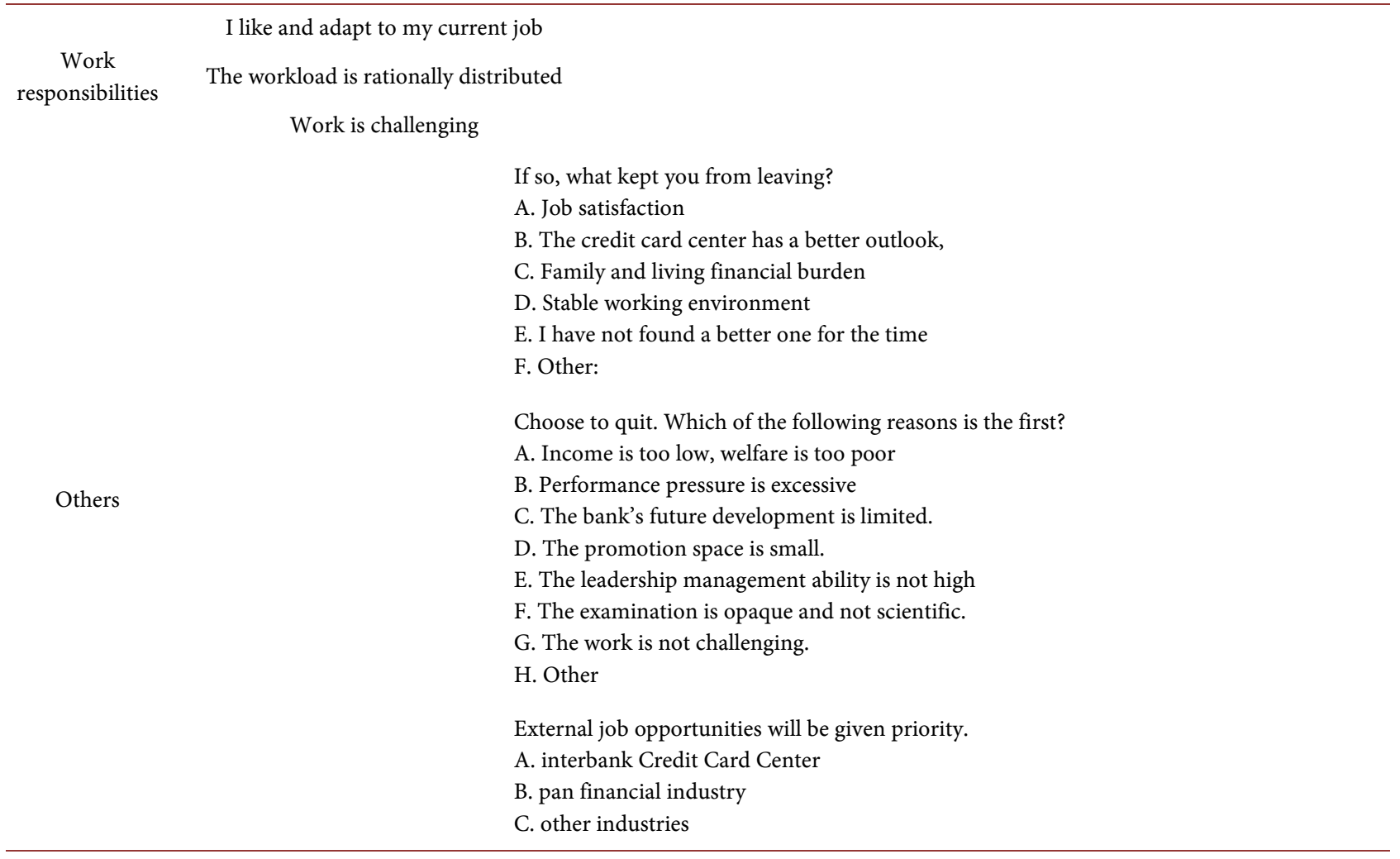

Part IV: according to your personal feelings, please predict and evaluate the effectiveness of the following measures to cope with the talent turnover, and type " $\sqrt{ }$ " in the most objective corresponding column.

\begin{tabular}{|c|c|c|c|c|c|c|c|}
\hline Number & Measures to deal with the talent turnover & $\begin{array}{l}\text { Very } \\
\text { effective }\end{array}$ & effective & $\begin{array}{c}\text { Generally } \\
\text { effect }\end{array}$ & $\begin{array}{c}\text { Minimal } \\
\text { effect }\end{array}$ & $\begin{array}{l}\text { Poor } \\
\text { effect }\end{array}$ & $\begin{array}{c}\text { Very poor } \\
\text { effect }\end{array}$ \\
\hline 1 & $\begin{array}{l}\text { Combined with data accumulation and analysis, combined } \\
\text { with the characteristics of industry and crowd, the } \\
\text { management system of credit card business was established. }\end{array}$ & & & & & & \\
\hline 2 & $\begin{array}{l}\text { Development of Credit Card products and } \\
\text { Operation system for different customer groups }\end{array}$ & & & & & & \\
\hline 3 & $\begin{array}{l}\text { Combine the innovation and evolution of } \\
\text { consumption and payment technology, enrich the } \\
\text { virtual credit card and entity card payment carrie }\end{array}$ & & & & & & \\
\hline 4 & $\begin{array}{l}\text { Establish a fair and reasonable performance appraisal } \\
\text { system to achieve rewards and penalties }\end{array}$ & & & & & & \\
\hline 5 & $\begin{array}{l}\text { Improve the transparency of management and } \\
\text { create an open and fair working environment }\end{array}$ & & & & & & \\
\hline 6 & $\begin{array}{l}\text { Establish a multi-channel promotion mechanism, } \\
\text { and give timely recognition to the outstanding employees }\end{array}$ & & & & & & \\
\hline 7 & Cultivate the team spirit of the staff & & & & & & \\
\hline 8 & Leaders care about respecting and trusting employees & & & & & & \\
\hline
\end{tabular}




\section{Continued}

10

increase employee's identity to the enterprise

Conduct emotional management and improve communication mechanism between superiors and subordinates

Improve the quality of leaders at all levels, strengthen

11 management skills training for managers, and create a healthy working environment

Provide opportunities for delegation of authority and participation in decision-making, and create a liberal environment within which to speak out

13

Provide individualized and effective training according to the needs of different positions

14

Organize activities of interest to employees and enhance their sense of belonging

15

Improve the career planning of employees and provide individual development channels

Establish personal growth files for employees and

16 provide feedback and reference to employees in due course

At the end of this questionnaire, thank you again for your cooperation and patience. I promise to keep your information strictly confidential. If you want to know the results of this study, please leave your email. I will send the results to your mailbox after the study. 